\title{
Bibliografia prac Kazimierza Twardowskiego i literatury o Kazimierzu Twardowskim
}

DOI: http://dx.doi.org/10.12775/RF.2018.004

\section{SPIS SKRÓTÓW}

A = Ateneum, Warszawa. - AGPh. = Archiv für Geschichte der Philosophie, Berlin. - A. K. = Ajdukiewicz K., Główne kierunki filozofii w wyjątkach z dzieł ich klasycznych przedstawicieli. Lwów, Jakubowski (1933). - AL = Lwów, H. Altenberg. - Brl. - Berlin. - Chw. = Chwila, Lwów. - Cz. - Czas, Kraków. - Dz. Lw. = Dziennik Lwowski. - DzP = Dziennik Polski, Lwów. - GłN - Głos Narodu, Kraków. - GP = Gazeta Poranna, Lwów. - GW = Gazeta Wieczorna, Lwów. - Halpern, AGPh. = Halpern I., Philosophiegeschichtliche Arbeit in Polen von Anfang 1910 bis Mitte 1911. - Archiv für Geschichte der Philosophie, XXV ('12). Halpern, Kronika = Halpern I., Kronika polskiej pracy filozoficznej. I. Przegląd Filozoficzny, XV ('12), - IKC = Ilustrowany Kurier Codzienny, Kraków. - KLw. = Kurier Lwowski. - Kr. = Kraków. - Krt. = Krytyka, Kraków. - Ks. = Książka, Warszawa. - Ks. pam. - Księga Pamiątkowa. KW = Kurier Warszawski. - Lg = Leipzig. - Lw. = Lwów. $-\mathrm{M}=$ Muzeum, Lwów. - MR = Kazimierz Twardowski. Mowy i Rozprawy z okresu Jego działalności w TNSW. Księga Pamiątkowa wydana przez TNSW. Lwów, 1912. - MST = Muzeum, Lwów. Sprawy Towarzystwa. - NP = Nauka Polska, Warszawa. - NR = Nowa Reforma, Kraków. - OeL = Oesterreichische Literaturzeitung, Wien. $-\mathrm{P}=$ Paris. - Pdr. = Przedruk. $-\mathrm{PF}=$ Przegląd Filozoficzny, Warszawa. - Pgl. = Przegląd polityczny, społeczny i literacki, Lwów. - PhG. = Philosophie der Gegenwart, hg. v. A. Ruge, Heidelberg. $-\mathrm{PH}=$ Przegląd Humanistyczny, Lwów. - PNL = Przewodnik Naukowy i Literacki, Lwów. - PP = Przegląd Polski, Kra- 
ków. - PPA = Przegląd Prawa i Administracji, Lwów. - PPed. - Przegląd Pedagogiczny, Warszawa. - PPw. = Przegląd Powszechny, Kraków. Pr. $=$ Program. - Prz. $=$ Przełom, Wiedeń. - Przem. $=$ Przemówienie. $-\mathrm{PTF}=$ Polskie Towarzystwo Filozoficzne we Lwowie. $-\mathrm{PWU}=$ Powszechne Wykłady Uniwersyteckie. Lwów. - RAF = Rozprawy i Artykuły Filozoficzne. Zebrali i wydali uczniowie. Lwów, Nakładem Komitetu uczniów, 1927. - RF = Ruch Filozoficzny, Lwów. - Rubczyński, Etyka = Rubczyński W. Etyka. Wydanie 2. "Zarysu etyki”, poprawione i rozszerzone. Lublin 1936. - Sl. R. = Slavische Rundschau. - SłP = Słowo Polskie, Lwów. - Spr. $=$ Sprawozdanie. $-\mathrm{W}=$ Wien. $-\mathrm{WKP}=$ Wiedeński Kurier Polski. - Wkr. = Widnokręgi, Lwów. - WN = Wiek Nowy, Lwów. - WW - Warszawa, Wende. - Wwa - Warszawa. - WZgr. = Walne Zgromadzenie. - Zj. Czł. = Zjazd Członków.

\section{A. Prace filozoficzne}

\section{ORYGINALNE PRACE I PRZYCZYNKI NAUKOWE}

\section{ROZPRAWY}

1. IDEE UND PERCEPTION. EINE ERKENNTNIS-THEORETISCHE UNTERSUCHUNG AUS DESCARTES. W., Konegen, p. 46. 23 x 15.

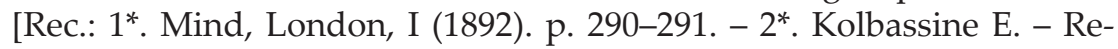
vue philosophique, P, XXXIV (1892). p. 444. - 3*. Schmidkunz H. - Vierteljahrsschrift f. wissenschaftliche Philosophie, Lg, XVI (1892). p. 369-370. - 4*. Adickes [E]. - Deutsche Literaturzeitung, Brl., XIV (1893). nr 35, p. 1112. - 5*. Zeitschrift für exakte Philosophie im Sinne des neuern philosophischen Realismus, Langensalza, XX (1893). p. 113. - 6*. Erdmann B. w „Bericht über die neuere Philosophie bis auf Kant für die Jahre 1890-1893, hg. v. W. Windelband. I. Descartes und Schule. Bericht v. B. Erdmann". - AGPh. VII (1894). p. 523-4. - 7*. Struve H. na str. 497-499 artykułu „Nowy pracownik na niwie naszej filozofii”. - Biblioteka Warszawska, LVI (1896). 3. str. 496-504. - 8*. Zob. też Łubnicki N. Les travaux polonais sur Descartes depuis 1900 environ. - Revue de Synthèse, P. XIV ('37). 1. p. 103].

2. ZUR LEHRE VOM INHALT UND GEGENSTAND DER VORSTELLUNGEN. EINE PSYCHOLOGISCHE UNTERSUCHUNG. W., Hölder, 1894, p. $11.23 \times 15$.

[Rec.: 9*. Schmidkunz H. - Oesterreichisch-Ungarische Revue, W., VII (1894). Bd. XV. 4. 5. p. 329-334. - 10*. Mind, London, III (1894). p. 274-5. $-11^{*}$. $\mu$. - The Monist, Chicago, V (1894/5). p. 149. $-12^{*}$. 
Schmidkunz H. - Zeitschrift für Philosophie und philosophische Kritik, Lg, CV (1895). p. 294-7. - 13*. Uphues G. K., Ueber den Gegenstand des Erkennens. - Neue Bahnen, Wiesbaden, VII (1896). 10. p. 527-535. - 14*. Offner M. - Zeitschrift für Psychologie und Physiologie der Sinnesorgane, Hamburg und Lg, X (1896). p. 468-9. - 15*. Grandgeorge L. - Revue philosophique, P. XLI (1896). p. 336-9. Struve H. na str. 499-504 artykułu jw. nr $7^{*}$. - 16* Natorp P. w „Bericht ueber deutsche Schriften zur Erkenntnistheorie aus dem Jahrgang 1894-1895. II." - Archiv für systematische Philosophie, Brl., III (1897). p. 198-201. - Zob. też m. i.: Uphues G. K., Die psychologische Grundfrage. Im Anschluss an die neuere psychologische Litteratur. S.-A. aus den Monatsheften der Comenius-Gesellschaft, 1895, marzec-kwiecień. Münster i. W., 1895. str. 5 i 17. - Meinong A., Ueber Gegenstande höherer Ordnung und deren Verhältnis zur inneren Wahrnehmung. - Zeitschrift für Psychologie, Lg, XXI (1899). uw. 1. p. 185. - Husserl E., Logische Untersuchungen, Halle a. S. 1900; 2. wyd. 1913. O poglądach Twardowskiego mowa explicite w t. II. cz. I. str. 50; 134-5 (2. wyd. 134-6); 215 (2. wyd. 217); 263 (2. wyd. 269); 289 (2. wyd. 297). - Stögbauer A., Kiedy wyobrażenia różne mają ten sam przedmiot? - PF, X ('07). str. 539; 541. - Kreibig J., Die intellektuellen Funktionen. W. u. Lg, '09, str. 23; 90; por. też 22; 32. - Ziehen Th., Lehrbuch der Logik auf positivistischer Grundlage. Bonn, '20. Zob. Spis osób s. v. Twardowski. - Höfler A., Logik, 2. Aufl. W. Lg, '22. M. i. str. 34; 55; 167, 168; 224; 437. - Tenże, Psychologie. 2. sehr verm. Aufl. Hg. u. m. Anm. vers. v. Dr A. Wenzl. I. Bd. W. - Lg, '30, str. 29-30 i uw. p. 29. Por. też I. wyd. tegoż dzieła, W. u. Prag, 1897, uw. 2 p. 3 oraz tegoż autora: Sind wir Psychologisten? Estr. degli Atti del V Congresso Internazionale di Psicologia. Roma, '05, p. 8. (Cf. Marty A. Untersuchungen zur allgemeinen Grammatik u. Sprachphilosophie. I. Halle a. S. '08, str. 388, 389). - Pastuszka J. Ks., Filozofia współczesna. T. II. Lublin, '36, str. 86. Zob. nadto poniżej w dziale C nry 141* (Kastil), 142* (Stögbauer), 145* (Tennerówna), 148* (Blaustein), 149* (Linke), 151* (Blaustein), 152* (Blausteinowa), 153* (Witwicki T.), 160* (Tenże) i 161* (Tenże).

3. PSYCHOLOGIA WOBEC FIZJOLOGII I FILOZOFII. - Przewodnik naukowy i literacki, Lw. XXX (1897). str. 17-41. (Także w odbitce. Lw., Gubrynowicz i Schmidt, 1897, Str. 30. 27,5 x 15). - Pdr.: RAF, str. 1-32. - 4. AUTOREFERAT. - PF, I (1897/8). 1. str. 87-88.

[Rec.: 17*. Pawlicki St. Ks. - PP. XXXII (1897). 2. t. 126. str. 479-82. - $18^{*}$. Kozłowski W. M. - A, XCVIII (1900). II. str. 198-9. - 19*. Mahrburg A. - PF, I (1897/8). 2. str. 71-9]. - 5. ODPOWIEDŹ NA KRYTYKĘ PRACY P. T. „PSYCHOLOGIA WOBEC FIZJOLOGII I FILOZOFII" PODANĄ PRZEZ P. A. MAHRBURGA. - Tamże, str. 145-8. - 
20*. Mahrburg A., Odparcie repliki Dra Twardowskiego. - Tamże, str. 149-151. - Zob. też 164* (Ks. Iwanicki), str. 392-4].

6. WYOBRAŻENIA I POJĘCIA. Lwów, w komisie Księgarni H. Altenberga, 1898, Str. 151.1 nl. 22 x 14. - 7. AUTOREFERAT. - PF, I (1897/9). 2, str. 68-9.

[Rec.: 21*. Dawid J. Wł. - Tamże, 4, str. 73-77. - 22*. Nuckowski J. Ks. PPw, XV (1898). t. 58. str. 251-256. - 23*. Pechnik A. Ks. - PP, CXXIII (1898). 1. str. 580-587. - 24*. Oświata (Pogląd na świat). Kr., nr z 15. 12. 1899. - 25*. Pręgowski P., Le concept, le jugement et l'attention. P, '27. Ocena teorii pojęć Twardowskiego (odnoszące się też do nru 67) na str. 38-58. (Por. autoreferat odczytu P. Pręgowskiego pt. „Teoria pojęć prof. Twardowskiego", wygłoszonego na 337. pos. Warszawskiego Twa Filozoficznego, 12. 11. '28. - RF, XI ('28/9), str. 175 b-180 a).-Zob. też m. i.: Mahrburg A., Poradnik dla samouków. Cz. I. wyd. 2. Wwa, '01, str. 628 i Cz. IV. '02, str. 67. - Rubczyński, Etyka. T. 3. str. 49 oraz poniżej w dziale C nry 142* (Stögbauer), 151* (Blaustein), 153* (Witwicki T.) i 160* (Tenże)].

8. W SPRAWIE KLASYFIKACJI ZJAWISK PSYCHICZNYCH. - Szkoła, Lw., XXXI (1898). nr 45, str. 405-406; nr 46, str. 413-15. - Pdr.: RAF, str. 33-42. [Zob. poniżej nr 76 i uw. 1] oraz 164* (Ks. Iwanicki), str. 394-5].

9. O TAK ZWANYCH PRAWDACH WZGLĘDNYCH. - Księga Pamiątkowa Uniwersytetu lwowskiego ku uczczeniu pięćsetnej rocznicy fundacji Jagiellońskiej Uniwersytetu krakowskiego. Lwów, nakładem Senatu Akademickiego Uniwersytetu lwowskiego, 1900, Str. 25. 27,5 x 20. - Pdr.: 1). RAF, str. 64-93. - 2). Biblioteczka Filozoficzna. Wydawnictwo PTF. T. 3. Lw. - Wwa, Książnica - Atlas, '34, str. 44. 21,5 x 14,5. - 10. Przekład niemiecki: UEBER SOGENANNTE RELATIVE WAHRHEITEN. Uebersetzt von M. Wartenberg. - Archiv. f. systematische Philosophie, Brl., VIII ('02). 4. p. 415-417. (Także w odbitce. $22,5 \times 15,5)$. - 11. AUTOREFERAT: O tak zwanych prawdach względnych (z Księgi Pamiątkowej jw.). - PF, IV ('01). 2. str. 207-8. Pdr.: RAF, str. 94-5.

[Rec.: 26*. Elmer B. w artykule „Przegląd ruchu filozoficznego”. - Krt., V ('03), 1. str. 251. - Zob. też Rubczyński, Etyka. T. 3. str. 75 i 164* (Ks. Iwanicki), str. 395-7].

12. WSTĘP DO POLSKIEGO PRZEKŁADU G. T. FECHNERA: Książeczka o życiu pośmiertnym. AL - WW., '07, str. 1-27. Zob. poniżej nr 219. - Pdr.: RAF, str. 246-60. - 13. AUTOREFERAT: Fechner G. T., Książeczka o życiu pośmiertnym. Przejrzał i wstępem opatrzył K. Twardowski. LW - Wwa, '07. - PF, XI ('08). 3. str. 214.

[Rec.: $27^{*}$. Strusiński W., De immortalitate animae. - SłP nr 26 z 16. I. '08, str. 1-2. - Zob. też 164* (Ks. Iwanicki), str. 400-1]. 
14. O CZYNNOŚCIACH I WYTWORACH. KILKA UWAG Z POGRANICZA PSYCHOLOGII, GRAMATYKI I LOGIKI. - Księga Pamiątkowa ku uczczeniu 250-tej rocznicy założenia Uniwersytetu lwowskiego przez króla Jana Kazimierza. T. II. Lwów, nakładem Uniwersytetu lwowskiego, 1912, str. 1-33. (Także w odbitce. Kr., '11, Str. 33. 26 x 17). - Pdr.: RAF, str. 96-128. - 15. Autoreferat niemiecki: UEBER FUNKTIONEN UND GEBILDE. EINIGE BEMERKUNGEN ZUM GRENZGEBIET DER PSYCHOLOGIE, GRAMMATIK UND LOGIK. - PhG. III ('11). str. 214.

[Rec.: 28*. Stamm E. - PF, XV ('12). str. 352-8. - 29*. Nawroczyński B.: Sąd - wytwór. Wobec teorii czynności i wytworów K. Twardowskiego. - PF, XVI ('13). str. 495-507. - 30*. Szycówna A. - Echo Literacko-artystyczne, II. 5., maj '13, str. 637-9. - 31*. Tatarkiewicz Wł. - Ks., XIII ('13). str. 7-8. - 32*. Kryński Przegonia M. Z. - Prace Filologiczne, Wwa, VIII ('16). 2. str. 321-6. - Spr.: Stögbauer A. - RF, XIII ('13). str. 132 a - 133 a. - Zob. też poniżej w dziale C nr 145* (Tennerówna)].

16. O PSYCHOLOGII, JEJ PRZEDMIOCIE, ZADANIACH, METODZIE, STOSUNKU DO INNYCH NAUK I O JEJ ROZWOJU. - Encyklopedia Wychowawcza, Wwa, 1913, t. 9. z. 1. str. 1-47. (Także w odbitce. Wwa, '13, Str. $50.26 \times 17$ ).

[Rec.: 33*. (k) - KW, nr 267 z 27. 9. '13, str. 3. - 34*. GW nr 1525 z 2. 10. '13. str. 7].

17. O POTRZEBACH FILOZOFII POLSKIEJ. - Nauka Polska, Wwa, I ('18). str. 453-86. - Pdr.: RAF, str. 129-63.

[Spr.: 35*. Gromska D. - RF, V ('19/20). str. 100 b - 101 b].

18. ROZPRAWY I ARTYKUŁY FILOZOFICZNE. - Zebrali i wydali Uczniowie. Lw., Książnica - Atlas, '27, Str. VI. 447. 23 x 15. [Zawiera niniejszej Bibliografii nry: 3, 8, 9, 11, 12, 14, 17, 19, 20, 21, 22, 24, $25-27,30,31,34-38,40,41-49,51-58,64,66,75,78-81,83,85,86,94$, $96-98,100]$.

[Rec.: 36*. R. L(utman). - Dz. Lw., nr 315 z 7. 11. '27, str. 5-6. - 37*. Warszawianka, nr. 33 z 2. 2. '28. - 38*. Kurier Literacko-Naukowy nr 37, str. VII. Dodatek do IKC, nr 251 z 10. 9. '28. - 39*. Kotarbiński T. Kwartalnik Filozoficzny, Kr., VI ('28). str. 102-4. - 40*. Kwiatkowski Fr. Ks. - PP, CLXXVII ('28). str. 145-6. - 41*. Auerbach W. - Kant-Studien, Brl. XXXIV ('29). p. 497-8 (po niemiecku). - 42*. L. B[laustein]: Wśród najlepszych książek filozoficznych (Rozprawy i Artykuły filozoficzne znalazły się wraz z dwiema innymi książkami filozoficznymi w r. 1927 wśród dwudziestu dzieł polskich tegoż roku, uznanych za „uwagi godne”, przez Polski Komitet Międzynarodowej Komisji Współpracy intelektualnej przy Lidze Narodów.). - Chw., nr 3737 z 18. 8. '29, str. 7. -43*. W. A[uerbach]. - PH, V ('30). str. 205-6. - Zob. też $164^{*}$ (Ks. Iwanicki)]. 


\section{ARTYKUŁY I ROZPRAWY MNIEJSZE}

19. FRYDERYK NIETZSCHE. - Prz., I (1895). nr 2-3 z 8. 6. str. 71-81. - Pdr.: RAF, str. 293-305. - [Zob. 164* (Ks. Iwanicki), str. 399400].

20. MONISTA - MISTYK. - Prz. jw., nr 5 z 22. 6. str. 144-56. - Pdr.: RAF, 293-305. - [Zob. 164* (Ks. Iwanicki), str. 401-2].

21. KULTURA ETYCZNA. - Prz. jw., nr 8 z 13. 7. str. 239-48. - Pdr.: RAF, str. 321-42.

22. FRANCISZEK BRENTANO A HISTORIA FILOZOFII. - Prz. jw., nr 11 z 3. 8. str. 335-46. - Pdr.: RAF, str. 229-42. - [Zob. 164* (Ks. Iwanicki), str. 400].

23. FILOZOFIA WSPÓŁCZESNA O NIEŚMIERTELNOŚCI DUSZY. Prz. jw., nr 14 z 24. 8. str. 427-38.

24. ETYKA WOBEC TEORII EWOLUCJI. - Prz. jw. nr 18 z 21. 9. str. 55163. - Pdr.: RAF, str. 343-56. - [Zob. Rubczyński, Etyka. T. 3. str. 75 i $164^{*}$ (Ks. Iwanicki), str. 397-8].

25. ERNEST KAPP. FILOZOFIA TECHNIKI. - Prz. II (1896). nr 12-14 z 4. 4. str. 284-90. - Pdr.: RAF, str. 285-92. - [Zob. 164* (Ks Iwanicki), str. 401-2].

26. CZY CZŁOWIEK POSTĘPUJE ZAWSZE EGOISTYCZNIE? - Iris, Lw. I (1899). 5. str. 211-6. (Także w odbitce, Str. 4.24 x 15). - Pdr.: RAF, str. 362-7. - [Zob. 164* (Ks. Iwanicki), str. 398-9].

27. PESYMIZM I OPTYMIZM. - Przyjaciel Młodzieży, Lw. I (1899). 8. 9. z 1. 9. str. 122-4. - Pdr.: 1) RAF, str. 357-61. - 2) Sygnały, Lw. nr 10-11 z 1. 9. '34, str. 21.

28. PRZEDMOWA DO WYDANIA POLSKIEGO Külpe'go „O zadaniach i kierunkach filozofii". - Lw. - Wwa, str. I-IV. Zob. poniżej nr 218.

29. [?] PRZEDMOWA DO 2. WYDANIA tegoż przekładu. - Lwów, (1910)? - Zob. poniżej nr 218 i uwagę.

30. NAUKA PROPEDEUTYKI FILOZOFICZNEJ W GIMNAZJACH. (Z powodu broszurki Prof. M. Straszewskiego „Propedeutyka filozoficzna w naszych gimnazjach"). - Tygodnik Słowa Polskiego, 1902, nr 14 z 5. 10., str. 5-6.

31. SPENCER I LEIBNIZ. - SłP nr 600 z 24. 12. '03, str. 7-8. - Pdr.: RAF, str. 266-9.

32. Z KONGRESU PSYCHOLOGÓW W GIESSEN. - SłP nr 193 z 23. 4. 1904, str. 2-3 i nr 197 z 26. 4. 1904, str. 3.

33. JAK STUDIOWAĆ FILOZOFIĘ? - Widnokręgi, Lwów, I ('10). 1. str. 1-4. - Pdr.: RAF, str. 172-6. - [Por. 44*. Moraczewski W. w artykule: Widnokręgi. - SłP nr 131 z 19. 3. '10, str. 8-9].

34. JESZCZE SŁÓWKO O POLSKIEJ FILOZOFII NARODOWEJ. - RF, I ('11). str. 113-5. - Pdr.: RAF, str. 391-3. - [Rec.: 45*. Słw. - SłP nr 341 
z 24. 7. '11, str. 8. - Zob. też Halpern, Kronika, str. 572. - Tenże, AGPh. str. 333.

35. FILOZOFIA NA ZJAZDACH LEKARZY I PRZYRODNIKÓW POLSKICH. - RF, I ('11). str. 137-9. - Pdr.: RAF, str. 369-71.

36. WPEYWY NIEMIECKIE W POLSKIEJ TERMINOLOGII FILOZOFICZNEJ. - Tamże, str. 185-7. - Pdr.: RAF, str. 206-9. [Zob. 164* (Ks. Iwanicki), str. 391].

37. KOMISJA HISTORII FILOZOFII POLSKIEJ. - Tamże, str. 205-7. Pdr.: RAF str. 372-4.

38. PSYCHOLOGIA BEZ PRZYRZĄDÓW. - Wiedza i Postęp, Kr., I ('12). 1. str. 1-8. (Także w odbitce, Str. 8. 25 x 19,5). - Pdr.: RAF, str. 316323. - [Zob. 164* (Ks. Iwanicki), str. 394]. - 39. Autoreferat niemiecki: PSYCHOLOGIE OHNE APPARATE. - PhG. IV ('12). p. 280.

40. SŁOWNIK FILOZOFICZNY FRANCUSKIEGO TOWARZYSTWA FILOZOFICZNEGO. - RF, II (' 12). str. 1-2. - Pdr.: RAF, str. 375-7.

41. CO ZNACZY DOŚWIADCZALNY? - RF, II ('12). str. 57-60. - Pdr.: RAF, str. 210-214. - 42. Autoreferat niemiecki: WAS BEDEUTET „DOŚWIADCZALNY”? - PhG, IV ('12). p. 159. - [Rec.: 46*. SłP nr 186 z 22. 4. '12. str. 9. - Zob. też $164^{*}$ (Ks. Iwanicki), str. 393].

43. HENRYK STRUVE. - RF, II ('12). str. 101-7. - Pdr.: RAF, str. 306-313.

44. PRACE POLSKIE W MIĘDZYNARODOWEJ BIBLIOGRAFII FILOZOFICZNEJ. ODEZWA DO POLSKICH AUTORÓW FILOZOFICZNYCH. - RF, II ('12). str. 181-2. - Pdr.: RAF, str. 378-80.

45. FILOZOFIA A PSYCHOLOGIA EKSPERYMENTALNA. - RF, III ('13). str. 81-5. (Bez podpisu). - Pdr.: RAF, str. 324-9.

46. W SPRAWIE POLSKICH PRZEKŁADÓW DZIEŁ FILOZOFICZNYCH. - RF, III ('13). str. 105-7. - Pdr.: RAF, str. 381-3. - [Zob. SłP nr 238 nr 24. 5. '13, str. 11].

47. GRANICE PURYZMU. - RF, III ('13). str. 185-9. (Także w odbitce. Str. 5). - Pdr.: RAF, str. 215-221. - [Rec.: 47*. W. D[o]br.[owolski]: Z dziedziny jabłek i... filozofii. - GW nr 1557 z 21. 10. '13, str. 4-5. - 48*. Mr. - SłP nr 495 z 23 10. '13, str. 9. - 49*. Kurier Polski, Wwa, nr 293 z 23. 10. '13, str. 1. - 50*. KW nr 293 z 23. 10. '13, str. 4].

48. DZIESIĘCIOLECIE POLSKIEGO TOWARZYSTWA FILOZOFICZNEGO. [Bez podpisu]. - RF, IV ('14-18). str. 57-9. - Pdr.: RAF, str. 384-6.

49. W SPRAWIE POLSKIEJ BIBLIOGRAFII FILOZOFICZNEJ. [Bez podpisu]. - RF, IV ('14-18). str. 93-5. - Pdr.: RAF, str. 387-9.

50. PO CZTERECH LATACH. [Bez podpisu. - Autentyczność poświadczona przez nr 206], - RF, IV ('14-18). str. 206-7.

51. FILOZOFIA W SZKOLE ŚREDNIEJ. - RF, V ('19-20). str. 1-6. - Pdr.: RAF, str. 177-184.

52. O JASNYM I NIEJASNYM STYLU FILOZOFICZNYM. - RF, V ('1920). str. 25-7. - Pdr.: RAF, str. 203-5. 
[Dyskusja ad 52: 51*. Metallmann J., O jasnym i niejasnym stylu filozoficznym. - RF, jw., str. 43-44. - 52*. Ingarden R., O jasnym i niejasnym stylu filozoficznym. - Tamże, str. 45-8. - 53*. Einhorn D., O jasnym i niejasnym stylu filozoficznym ze stanowiska teorii poznania i metodologii. - Tamże, str. 71-4. - Zob. też 164* (Ks. Iwanicki), str. 391].

53. O WYKSZTAŁCENIE LOGICZNE. - Tamże, str. 65-71. - Pdr.: RAF, str. 185-93.

54. O PRZYGOTOWANIU NAUKOWYM DO FILOZOFII. - RF, V ('19-20). str. 97-9. - Pdr.: RAF, str. 194-7.

[Rec. nrów 51, 53 i 54: 54*. j. - M, XXXV ('20). str. 59-60. - Ad nr 54 zob. też 55*: Tydzień Polski, Wwa, I ('20). 11. str. 16].

55. CO ZNACZY „FIZYCZNY”? - RF, V ('19-20). str. 121-6. - Pdr.: RAF, str. 222-8.

56. KILKA UWAG O MINISTERIALNYM PROJEKCIE PROGRAMU NAUKI FILOZOFII W SZKOLE ŚREDNIEJ. - RF, V ('19-20). str. 177-81. - Pdr.: RAF, str. 198-202.

57. WSTĘP DO POLSKIEGO PRZEKŁADU Fechnera, O Zagadnieniu Duszy. - Lw., '21. str. I-X. Zob. poniżej nr 220. - Pdr.. RAF, str. 260265.

58. SYMBOLOMANIA I PRAGMATOFOBIA. - RF, VI ('21). str. 1-10. Pdr.: RAF, str. 394-406. - [Zob. 56*. Błachowski St. Zagadnienie twórczości naukowej. - NP, IX ('28). str. 39-41].

59. PROGRAM NAUCZANIA PSYCHOLOGII W SZKOLE ŚREDNIEJ (,ustalony przez Polskie Towarzystwo Filozoficzne na podstawie referatu Prof. Dr K. Twardowskiego"). - M, XXXVI ('21). str. 28-33.

60. PO I. POLSKIM ZJEŻDZIE FILOZOFICZNYM. - RF VII ('22-23). str. 129-32.

61. SOKRATES. - Filomata, Lw., '31, L. 29. str. 590-9.

62. WIĘCEJ FILOZOFII! - RF, XIII. 1-4 ('35). str. 1-5.

63. ANKIETA I KWESTIONARIUSZ. - Tamże, str. 63 a-b.

\section{ODCZYTY I WYKŁADY}

a) Odczyty i wykłady drukowane w całości

64. PSYCHOLOGIA NAUKI POGLĄDOWEJ. Odczyt wygłoszony na otwarciu Krajowej Konferencji Nauczycieli szkół ludowych we Lwowie, dn. 24. 8. 1899 r. - Szkoła, Lw., XXXII (1899). nr 50. str. 473-5; nr 52. str. 493-5. - Pdr.: 1) w dziele "Z psychologii i fizjologii wychowania". Wiedza i Życie, R. I. t. XII. Lw. - Wwa, 1899, str. 102-135. -2) RAF, str. 43-63.

[Rec.: 57*. Szycówna A. - PPed., XXII ('03). 4. str. 46].

65. UEBER BEGRIFFLICHE VORSTELLUNGEN. Vortrag gehalten am 18. November 1902 in der Philosophischen Gesellschaft an der Uni- 
versität zu Wien. - Wissenschaftliche Beilage zum 16. Jahresberichte der Gesellschaft. In Kommision bei J. A. Barth. Lg, Verlag der Philos. Gesellschaft an der Univ. zu Wien, 1903, p. 1-28. (Także w odbitce. Lg, 1903, Str. 28.23 x 15,5). - 66. AUTOREFERAT. - PF, VII ('04). 3. str. 329-330. - Pdr.: RAF, str. 409-10.

[Rec.: 58*. Kreibig J. - Zeitschrift f. Psychologie. Lg, XLI ('06). p. 205-6. Zob. nadto nry 25* (Pręgowski) i 142* (Stögbauer)].

67. O ISTOCIE POJĘĆ. [Przekład polski odczytu Ueber bergriffliche Vorstellungen, dokonany przez autora, rozszerzony o Przedmowę [zob. poniżej w dziale "Varia“" nr 137 - uw. 1 na str. 33, oraz nieco zmieniony (uw. 1 str. 2) Lw., nakładem PTF. Odczyty filozoficzne, II. 1924, str. VI. 38, 21 x 15.

[Rec.: 59 . Czeżowski T., Teoria pojęć Kazimierza Twardowskiego. - PF, XXVII ('25). str. 106-110. - Por. Błachowski S. Stanje psihologijskih istrazivanje u Polskoj godine 1924 i 1925. - Revija za filozofiju i psyhologiju, Zagreb, I ('27). str. 93. - Rubczyński, Etyka. T. III. cz. 4 i 5. str. 49. Zob. też poniżej w dziale C nr $160^{*}$ (Witwicki T.) i $161^{*}$ (Tenże)].

68. Z KONGRESU PSYCHOLOGII EKSPERYMENTALNEJ odbytego w kwietniu [1904] w Giessen. (Rzecz czytana na pos. Polskiego Towarzystwa Filozoficznego, 21. grudnia 1904). - PF, VIII ('05). 1. str. 91-101.

69. O METODZIE PSYCHOLOGII. PRZYCZYNEK DO METODOLOGII PORÓWNAWCZEJ BADAŃ NAUKOWYCH. Odczyt wygłoszony na I ogólnym zebraniu I Zjazdu neurologów, psychiatrów i psychologów polskich w Warszawie w 1909 r. - Prace I Zjazdu jw. w Warszawie 11-12-13 Października 1909 r. Warszawa, 1910. str. 5-16. (Także w odbitce. AL - WW, 1910. Str. 18. 23 x 16). - 70. Autoreferat francuski: SUR LA MÉTHODE EN PSYCHOLOGIE. - Prace I. Zjazdu jw., str. 987. - 71. Autoreferat niemiecki: UEBER DIE METHODE DER PSYCHOLOGIE. EIN BEITRAG ZUR VERGLEICHENDEN METHODOLOGIE DER WISSENSCHAFTLICHEN FORSCHUNG. PhG III ('11). p. 272. - [Zob. też streszczenie odczytu pt. „Psychologia pod względem metodologicznym" wygłoszonego na (94). posiedzeniu PTF we Lwowie (12. 3. 1910). - SłP nr 143 z 26. 3. '10, str. 6].

[Rec.: 60*. B(iegeleisen) B. - Wkr, I ('10). 2. str. 55-8. - 61*. Segał J. - Ks., XI ('11). str. 331-3. - 62*. Schmidt W. - Miesięcznik Pedagogiczny, Cieszyn, XXIII ('13). - Zob. też Halpern, Kronika, str. 558. - Tenże, AGPh. p. 480].

72. O NAUKACH APRIORYCZNYCH CZYLI RACJONALNYCH (DEDUKCYJNYCH) I NAUKACH APOSTERIORYCZNYCH CZYLI EMPIRYCZNYCH (INDUKCYJNYCH). [Odczyt wygłoszony na 231. posiedzeniu naukowym Polskiego Towarzystwa Filozoficznego we Lwowie, dn. 14. 10. 1922]. - W książce: A. K., str. 180-190. 
b) Odczyty i wykłady drukowane w autoreferatach i programach

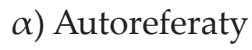

73. JAK I CZEGO NALEŻY SIĘ UCZYĆ? Streszczenia odczytów Twa Oświaty ludowej we Lwowie. Streszczenia odczytów urządzonych w jesieni i zimie 1898/99 we Lwowie, Lw., 1899, str. 1-14. - 74. Z ESTETYKI MUZYKI. Streszczenie odczytu wygłoszonego 19.10. 1899 w sali ratuszowej lwowskiej. - Przegląd polityczny, społeczny i literacki, Lw., nr 243 z 24. 10. 1899, str. 1-2. [Autentyczność poświadczona przez spuściznę rękopiśmienną]. -[Zob. SłP nr 249 z 20. 10. 1899, str. 3]. - 75. O POJĘCIU POCZYTALNOŚCI KARNEJ W ŚWIETLE PSYCHOLOGII. Tezy sformułowane na podstawie odczytu, wygłoszonego na posiedzeniu Twa Prawniczego we Lwowie, dn. 25. 3. 1899. - PPA, XXIV (1899). str. 318-9. - Pdr.: RAF, str. 446-7. - 76. W SPRAWIE KLASYFIKACJI ZJAWISK PSYCHICZNYCH. [Autoreferat odczytu wygłoszonego na posiedzeniu Sekcji Psychologicznej IX. Zjazdu lekarzy i przyrodników polskich dn. 22. 7. 1900] [Odczyt porusza inne zagadnienia aniżeli rozprawa pod tym samym tytułem (nr 8).]. - Dziennik IX. Zjazdu jw., Kr., 1900, str. 70. - [Zob. 164* (Ks. Iwanicki), str. 398]. - 77. GŁOS W DYSKUSJI (dwukrotnie) nad powyższym odczytem. - Tamże. [Spr. ad 76: 63*. Kozłowski W. M., Sekcja psychologiczna IX. Zjazdu przyrodników i lekarzy polskich w Krakowie. - PF, III (1900). str. 109]. - 78. W SPRAWIE KLASYFIKACJI UCZUĆ. [Odczyt, wygłoszony na 26. pos. naukowym PTF, 26. 10. 1905]. - PF, IX ('06). 1. str. 82-3. - Pdr.: RAF, str. 411-3. - 79. PRAWDOMÓWNOŚĆ JAKO OBOWIĄZEK ETYCZNY. [Zagajenie dyskusji na 29. pos. naukowym PTF, 13. 12. 1905]. - PF, IX ('06). str. 84-5. - Pdr.: RAF, str. 414-5. - 80. O ZADANIACH ETYKI NAUKOWEJ. [Odczyt wygłoszony w Związku Naukowo-Literackim we Lwowie, 10. 1. 1907]. - PF, X ('07). 1. str. 143-4. - Pdr.: RAF, str. 416-7. - [Spr. 64*. W. S[trusiński]. - SłP nr 21 z 12. 1. '07, str. 5-6. Por. też Rubczyński, Etyka. t. III. cz. 4. i 5. str. 75]. - 81. O IDIO I ALLOGENETYCZNYCH TEORIACH SĄDU. [Referat wygłoszony na Sekcji filozoficznej X. Zjazdu lekarzy i przyrodników polskich we Lwowie w r. 1907]. - PF, X ('07). 4. str. 467-8. - Także w: Sprawozdanie z posiedzeń naukowych w Sekcjach X. Zjazdu lekarzy i przyrodników polskich we Lw. Lw., '07/8. str. 83-4. Pdr.: RAF, str. 418-20. [Zob. nr 145* (Tennerówna) i 164* (Ks. Iwanicki), str. 394-5]. - 82. GŁOS W DYSKUSJI nad powyższym referatem. - PF. jw. str. 4789. - Sprawozdanie jw. str. 84. - 83. W SPRAWIE KLASYFIKACJI POGLĄDÓW NA WZAJEMNY STOSUNEK DUSZY DO CIAŁA. [Odczyt wygłoszony na 72. pos. naukowym PTF, 21. 11. 1908]. - PF, XII ('09). 2. str. 211-2. - Pdr.: RAF, str. 411-3. - 84. FILOZOFIA W EN- 
CYKLICE PASCENDI DOMINICI GREGIS. [Odczyt wygłoszony na 79. pos. naukowym PTF, 12. 2. 1909]. - PF, XII ('09). str. 560. - [Zob. GLw. nr 37 z 17. 2. '09, str. 3. - Zob. też z 16. 2. '09: DzP nr 847, str. 5; KLw. nr 144, str. 2. - Z 17. 2. '09: Pgl nr 38, str. 3; WN nr 2285, str. 5]. - 85. STRESZCZENIE ODCZYTOW Prof. K. Twardowskiego. (Drukowane jako rękopis dla użytku słuchaczy powyższych odczytów). Wwa, 1910. Str. 6. - Pdr.: RAF, str. 423-6. - [Rec.: 65*. A. - Wkr., I ('10). 1. str. 125-6. - 66*. Bell. Z życia umysłowego Warszawy. - KLw, nr 144 z 29. 3. '10, str. 1-2. - 67*. L. Z. Odczyty Prof. K. Twardowskiego. - Wychowanie w domu i w szkole, Wwa, III ('10). t. I. str. 392-3. - 68*. Weryho Wł., Filozofia w pedagogice. - KW nr 87 z 30. 3. '10, str. 2. - 69*. Odczyty Prof. Twardowskiego w Warszawie. - M, XXVI ('10). t. I. str. 544-6. - Zob. też Nowe Tory, Wwa, V ('10). t. 1. str. 382 i 164* (Ks. Iwanicki), str. 390]. - 86. HISTORYCZNE POJĘCIE FILOZOFII. [Odczyt wygłoszony w Sekcji Filozoficznej XI. Zjazdu lekarzy i przyrodników polskich w Krakowie, dn. 18. 7. 1912]. - Księga Pamiątkowa XI. Zjazdu jw. w Krakowie, 18.-22. 7. '12. Nakładem Komitetu Gospodarczego. str. 90-2. - Pdr.: RAF, str. 427-8. - 87. GŁOS W DYSKUSJI nad tym odczytem. - Ks. Pam. jw. str. 93-4. - 88. AUTOREFERAT (krótszy) odczytu nr 86. w „Sprawozdanie z obrad Sekcji filozoficznej XI. Zjazdu lekarzy i przyrodników polskich". - RF, I ('11), str. 162. - [Zob. Halpern, Kronika, str. 555. - Tenże, AGPh. p. 476. Zob. też streszczenie wykładu pt. Pojęcie filozofii, wygłoszonego w Stanisławowie w Związku Naukowo-Literackim, 6. 3. '14. - Kurier Stanisławowski, nr 1489 z 15. 3. '14, str. 2]. - 89. NAUKI HUMANISTYCZNE A PSYCHOLOGIA. [Odczyt wygłoszony na 130. pos. naukowym PTF, 12. 10. '12. - RF, II ('12). str. 200 a-b. - 90. KOMUNIKAT w sprawie pewnego poglądu Ks. A. Tylkowskiego, [wygłoszony na 147. pos. naukowym PTF, 31. 10. '13]. - RF, III ('13). str. 253 a-b. - 91. O PRAWDZIE FORMALNEJ. [Odczyt, wygłoszony na 226. pos. naukowym PTF, 11. 2. '22]. - RF, VII ('22-23). str. 37 b-38 a. - 92. Z LOGIKI PRZYMIOTNIKÓW. [Wykład, wygłoszony na I. Polskim Zjeździe Filozoficznym we Lwowie, 10.-13. 5. 1923]. - Księga Pamiątkowa tegoż Zjazdu, PF, XXX ('27) 4. str. 292 (40). - 294 (42). - 93. PRZYKŁAD WPŁYWU WYOBRAŻEŃ SŁUCHOWYCH NA WZROKOWE. - Tamże, str. 306 (54) - 310 (58). - 94. PSYCHOLOGIA MYŚLENIA. Streszczenie wykładów wygłoszonych w Uniwersytecie lwowskim w półroczu zimowym 1909/10. Skrypt hektografowany. Str. 31. - To samo. Cz. II. (półrocze letnie 1909). Streszczenia dyktowane słuchaczom przez Profesora. Nie zostały powielone. Zachowane są w rękopisach słuchaczy, oraz w spuściźnie rękopiśmiennej. - 95. GŁÓWNE KIERUNKI ETYKI NAUKOWEJ. Streszczenia dyktowane jw. w półroczu zimowym 1909/10. Nie zostały powielone. Zachowane są jw. 


\section{$\beta)$ Programy}

96. ŻYCIE UMYSŁOWE CZŁOWIEKA. - Progr. PWU, (1899). R. I. Seria I. Listopad - grudzień 1899, str. 9-12. (Także w odbitce, str. 1-4. - Pdr.: RAF, str. 429-34. - 97. MYŚL I MOWA. Odczyty Twa Oświaty Ludowej we Lwowie. Lw., (1900). Odczyt VI. Str. 9. - Pdr.: RAF, str. 4357. - 98. FILOZOFIA GRECKA. Progr. PWU. Lw., (1900). R. II. Seria I. Listopad i grudzień 1900, str. 9-12. - Pdr.: RAF, str. 438-41. - 99. ZARYS PSYCHOLOGII. Cz. I. - Progr. jw. 1901. R. III. Seria I. Listopad i grudzień 1901, str. 14-15. - Cz. II. Tamże, Seria II. Styczeń i luty 1902, str. 9. - Cz. III. Tamże. Seria III, Luty i marzec 1902, str. 7-8. 100. DUSZA I CIAŁO. HISTORYCZNY PRZEGLĄD GŁÓWNYCH TEORYJ O ICH WZAJEMNYM STOSUNKU. - Tamże. Lw., 1904. R. IV. Seria II. Styczeń i luty 1903, str. 6. - Seria III. Luty, marzec i kwiecień 1903, str. 13. - Pdr.: RAF, str. 444-5. - 101. KRÓTKI ZARYS LOGIKI. Cz. I. Progr. PWU. Lw., 1904. R. V. Seria II. Styczeń i luty 1904, str. 11. - Cz. II. Tamże. Seria III. Luty i marzec 1904, str. 1112. - 102. GŁÓWNE PRĄDY W FILOZOFII WIEKU XIX. - Progr. PWU. Lw., 1904. R. VI. Seria I. Listopad i grudzień 1904, str. 11-12. Pdr.: RAF, str. 442-3. - 103. O PAMIĘCI. - Progr. PWU. Lw., 1905. R. VII. Seria I. Listopad i grudzień 1905, str. 12. - 104. O FILOZOFII ŚREDNIOWIECZNEJ. - Tamże. Seria II. Styczeń i luty 1906, str. 1213. - 105. O PRZESĄDACH. - Tamże. Seria III. Luty-kwiecień 1906, str. 13. - 106. PSYCHOLOGIA UCZUĆ. - Progr. PWU. R. VIII- Seria III. Luty i marzec 1907, str. 8-9.

\section{c) Odczyty i wykłady drukowane w streszczeniach}

(Streszczeniami nazywam tu takie przedstawienia toku głównego myśli odczytów i wykładów, które nie pochodzą od prelegenta, lecz z kół słuchaczy. Zamieszczając streszczenia te $\mathrm{w}$ dziale $\mathrm{A}$, a nie $\mathrm{w}$ dziale $\mathrm{C}$ niniejszej Bibliografii, uczyniłam to dlatego, ponieważ streszczenia te są bądź co bądź źródłem poznania odnośnych poglądów Twardowskiego, źródłem - jeśli nie autentycznym, to na razie - jedynym. Spuścizna rękopiśmienna Twardowskiego, zawierająca tok myśli sześciu z tych ośmiu odczytów - niektóre z nich może nawet w całości - okaże, czy i o ile streszczenia powyższe odpowiadały intencjom prelegenta. Nie jest też wykluczone, że pewne streszczenia okażą się po zbadaniu wspomnianej spuścizny autoreferatami.)

(Znakiem † oznaczone są odczyty i wykłady, które znajdują się $\mathrm{w}$ formie zupełnej lub skróconej w spuściźnie rękopiśmiennej $\mathrm{K}$. Twardowskiego.)

$70^{*}$. † O stosunku filozofii greckiej do indyjskiej. Odczyt wygłoszony na

23. pos. Twa Filologicznego we Lwowie, 11. 4. 1896. - Eos, Lw., III 
(1896). str. 228 [Autoreferat?]. - Zob. też GLw nr 87 z 16. 4. 1896, str. 4. - Głos w dyskusji nad tym odczytem. - Eos, jw. - 71*. † O indukcji w metafizyce. Odczyt wygłoszony na pos. Twa przyrodników im. Kopernika, 1. 6. 1897. - GLw. nr 127 z 5. 6. 1897, str. 3. - GN nr 156 z 6. 6. 1897, str. 2. - KLw. nr 155 z 5. 6. 1897, str. 2. - SłP nr 127 z 2 (3). 6. 1897, str. 2. - 72*. † O estetyce eksperymentalnej. Odczyt wygłoszony w Czytelni Kobiet we Lwowie, 18. 2. 1899. - SłP nr 44 z 21. 2. 1899, str. 3. - 73*. † O sile uczuć. Odczyt wygłoszony w Związku Naukowo-Literackim we Lwowie, 25. 10. 1900. - Pgl. nr 246 z 27. 10. 1900, str. 2-3. - 74*. O formalizmie logicznym w myśleniu. Odczyt wygłoszony w Polskim Twie Przyrodników im. Kopernika, 19. 3. 1901. - SłP nr 135 z 21. 3. 01, str. 3. - 75*. † Filozofia w XIX. wieku. Odczyt wygłoszony we Lwowie, w sali obrad Rady miejskiej w cyklu „Wiedza i Życie w XIX stuleciu”, 14. 3. 1902. [Odczyt był krótszym ujęciem wywodów, rozwiniętych w nrze 102, który jest programem sześciu wykładów]. - KLw. nr 80 z 21. 3. '02, str. 7 w artykule "Filozofia w XIX stuleciu” (streszczenie i ocena). - SHP nr 132 z 19. 3. '02, str. 2-3. - 76*. + Co to jest filozofia i po co się jej uczymy. - Gazeta Sanocka I ('04). nr 47 z 20. XI. '04, str. 3 (w artykule „Powszechne Wykłady Uniwersyteckie“). - 77*. Leibniz o Polsce. Odczyt wygłoszony na 162 pos. naukowym PTF, 12. 2. '16. - GPor. nr 2732 z 14. 2. '16, str. 3-4.

\section{PRZEMÓWIENIA}

a) Przemówienia drukowane w całości

107. Przemówienie na OTWARCIU POLSKIEGO TOWARZYSTWA FILOZOFICZNEGO we Lwowie. - PF, VII ('04). 2. str. 239-43. - [Zob. z 14. 2. '04: DzP nr 74, str. 2. - GLw. nr 36, str. 4. - KLw. nr 45, str. 6].

108. Przemówienie [Dziekana Wydz. filozof. Uniw. lwowskiego] na promocji SUB AUSPICIIS IMPERATORIS [Dra B. BANDROWSKIEGO, 15. 5. 1905]. - GLw. nr 111 z 16. 5. '05, str. 4-5. - [Zob. DzP nr 223 z 16. 5. '05, str. 2. - SłP nr 225 z 15. 5. '05, str. 8].

109. Słowa pamięci o WOJCIECHU DZIEDUSZYCKIM, [wygłoszone przed wykładem w Uniwersytecie lwowskim, 24. 3. 1909]. - GLw. nr 69 z 27. 3. '09, str. 5-6. - SłP nr 140 z 25. 3. '09, str. 3.

110. GŁOS W DYSKUSJI nad referatem A. SZYCÓWNY pt. Zasady dydaktyki współczesnej a szkoła polska, wygłoszonym na 2. Polskim Kongresie Pedagogicznym we Lwowie, 1. 11. 1909. - Ks. Pam. tegoż Zjazdu, Lw. 1909, str. 99. - [Zob. z 2. 11. '09: Dz P nr 493, str. 3; GLw. nr 251, str. 4; KLw. nr 511, str. 2-3; SłP nr 511, str. 2. - Z 3. 11. '09: Pgl. nr 251, str. 2. - WN nr 2497, str. 6]. 
111. ZAGAJENIE I. POLSKIEGO ZJAZDU FILOZOFICZNEGO WE LWOWIE W 1923 R. - Księga Pamiątkowa tegoż Zjazdu, PF, XXX ('27), 4. str. 260 (8) - 265 (13). - [Zob. SłP nr 128 z 12. 5. '23, str. 4. WN nr 6567 z 13. 5. '23, str. 4].

112. PRZEMÓWIENIE WYGŁOSZONE NA ZEBRANIU JUBILEUSZOWYM POLSKIEGO TOWARZYSTWA FILOZOFICZNEGO WE LWOWIE DN. 12 LUTEGO 1929 R. - Życie kulturalne, nr 7, Dodatek do Słowa Polskiego nr 64 z 4. 3. '29, str. 7-9. (Także w odbitce nieprzeznaczonej do handlu księgarskiego. Lw., 1929, Str. 31.16 x 11,5). To samo [z kilku zmianami i uzupełnieniami zwłaszcza w cz. II]. pt. PRZEMÓWIENIE WYGŁOSZONE NA OBCHODZIE DWUDZIESTOPIĘCIOLECIA POLSKIEGO TOWARZYSTWA FILOZOFICZNEGO WE LWOWIE, DN. 12 LUTEGO 1929 R. W: „Księga Pamiątkowa PTF“. Lw., 1931. str. 1-5. (Także w odbitce. Lw., 1931, Str. 14. $25 \times 17,5)$.

[Rec.: 78*. Kwiatkowski W. Ks., Pseudokrytycyzm naukowy. - Gazeta Kościelna, Lw., XXXVI ('29). 17. z 28. 4. str. 199-200 i 18. z 5. 5. str. 210-12. - 79*. Geblewicz E. - PF. XXXVI ('33). str. 188. - 80*. Witwicki T. - PH, VI ('31). str. 216-17. - Zob. też RF, XI ('28-29). str. 199 a].

113. PODZIĘKOWANIE, które wygłosił Prof. Dr K. Twardowski w niedzielę, dn. 11. stycznia 1931 r. w Sali posiedzeń Seminarium filozoficznego Uniwersytetu Jana Kazimierza na UROCZYSTOŚCI WRĘCZENIA MU MEDALU PAMIĄTKOWEGO, wybitego staraniem byłych jego uczniów. (Drukowane jako rękopis). Str. 3.

114. POWITANIE PROF. DRA H. SCHOLZA na 320. plenarnym pos. naukowym PTF, dn. 25. 10. 1932. - RF, XIII. 1-4 ('35). str. 41 b-42 a.

115. PRZEMÓWIENIE WYGŁOSZONE Z OKAZJI WRĘCZENIA NAGRODY MIASTA ŁODZI. - Dziennik Zarządu Miejskiego w Łodzi, t. XIII, nr 11 z 5. 11. 1936, str. 778-80.

b) Przemówienia drukowane w autoreferatach i streszczeniach

(Rozgraniczenie autoreferatów od streszczeń jest w tej rubryce nie do przeprowadzenia. Autoreferatem jest na pewno tylko nr 132. I tutaj poznanie spuścizny rękopiśmiennej K. Twardowskiego usunie - być może - niejedną wątpliwość.)

116. GŁOS W DYSKUSJACH nad referatami wygłoszonymi na posiedzeniach SEKCJI PSYCHOLOGICZNEJ IX. ZJAZDU LEKARZY I PRZYRODNIKÓW POLSKICH w Krakowie, w r. 1900. - Dziennik tegoż Zjazdu. Kr., 1900. (1. Głos w dyskusji nad referatem A. Szycówny: Psychologia dziecka wobec psychologii ogólnej i pedagogicznej. str. 69. - 2. Dtto nad ref. J. Kodisowej: Istota pojęć naukowych. str. 70. - 3. Dtto nad ref. Wł. Biegańskiego: Analiza psychologiczna 
pewników logiki. str. 131. - 4. Dtto nad ref. W. M. Kozłowskiego: Połączenie chemiczne jako problemat teorii poznania. str. 132. - 5. Dtto nad ref. Dra A. Złotnickiego : Paralelizm psychofizyczny. str. 132. 6. Dtto nad ref. R. Radziwiłłowicza: W sprawie ustalenia naszego mianownictwa duchoznawczego (terminologii psychologicznej). str. 135. - 117. Przem. w czasie ANKIETY W SPRAWIE NAUCZANIA PROPEDEUTYKI FILOZOFICZNEJ W GIMNAZJACH. - PF, VI ('03). 1. str. 241-2; 242; 243. - [Spr. z przemówienia na I. pos. tejże Ankiety KLw. nr 353 z 21. 12. '02, str. 8. - Zob. też GLw. nr 292 z 21. 12. '02, str. 4; z przemówień w dyskusji na II. i III. pos. tejże Ankiety GLw. nr 293 z 23. 12 '02, str. 5]. - 118. Przem. [Promotora] na promocji Sub auspiciis imperatoris Dra J. ŁUKASIEWICZA, dn. 16. 11. 1902. - GLw. nr 263 z 16. 11. '02, str. 4. - SłP nr 553 z 16. 11. '02, str. 8. [Zob. też DzP. nr 535 z 16. 11. '02, str. 2]. - 119. Przem. wygłoszone na uroczystości DZIESIĘCIOLECIA PRACY W KÓŁKU FILOZOFICZNYM dn. 22. 11. 1905 - w artykule L. Wołowicza: Uczczenie Prof. Twardowskiego, zob. niżej nr 174*. - 120. ZAGAJENIE GOSPODARZA SEKCJI (Filozoficznej X. Zjazdu lekarzy i przyrodników polskich we Lwowie, dn. 25. 7. 1907). - PF, X ('07). str. 467-8 oraz Spr. z posiedzeń naukowych w Sekcjach X. Zjazdu jw. Lw. 1907/08. str. 82. - 121. GŁOS W DYSKUSJACH nad referatami wygłoszonymi w tejże SEKCJI. (1. Głos w dyskusji nad referatem Wł. Biegańskiego: Analogia i jej znaczenie w badaniu naukowym. - PF. jw. str. 488. Spr. jw. str. 85 (W „Sprawozdaniu” tytuł referatu Biegańskiego brzmi: Znaczenie analogii w badaniu naukowym.). 2. Dtto nad ref. J. Łukasiewicza: Logika a psychologia. - PF. jw. str. 492. Spr. jw. str. 86. - 3. Dtto nad ref. B. Bandrowskiego: Psychologiczna analiza zjawisk myślenia. - PF. jw. 531. Spr. jw. str. 89. - 4. Dtto nad ref. A. Szycówny: Psychologia dziecka w początkach XX wieku. - PF. jw. str. 548. Spr. jw. str. 91. -5. Dtto nad ref. J. Kurnatowskiego: Zrzeszenie jako czynnik etyczny. - PF, jw. str. 569. Spr. jw. str. 92). - 122. ZAGAJENIE V WALNEGO ZGROMADZENIA POLSKIEGO TOWARZYSTWA FILOZOFICZNEGO we Lwowie, dn. 12. 2. 1909. - [Autoreferat?]. DzP. nr 84 z 16. 2. '09, str. 5. - GLw. nr 37 z 17. 2. '09, str. 3. - KLw. nr 76 z 16. 2. '09, str. 2. - Pgl. nr 38 z 17. 2. '09, str. 3. - WN nr 2285. z 17. 2. '09, str. 5. - 123. Słowa pamięci O WOJCIECHU DZIEDUSZYCKIM, wygłoszone na 81. pos. PTF, dn. 27. '09. - GLw. nr 74 z 2. 4. '09, str. 3. - SłP nr 154 z 2. 4. '09, str. 6. - 124. GŁOS W DYSKUSJACH nad referatami, wygłoszonymi W SEKCJI PSYCHOLOGICZNEJ I ZJAZDU NEUROLOGÓW, PSYCHIATRÓW I PSYCHOLOGÓW POLSKICH w Warszawie w 1909 r. - Prace I Zjazdu jw., Wwa, 1910. (1. Głos w dyskusji nad referatem Wł. Biegańskiego: O postrzeżeniach. str. 765. - 2. Dtto nad ref. J. Wasserberga: Progi pobudliwości nerwowej w świetle zasady selekcji. str. 787. - 3. Dtto nad 
ref. I. Halperna: O zadaniach psychologii. str. 806; 807-8. - 4. Dtto nad ref. J. Segała: Spostrzeżenia nad wyobrażeniami odtwórczymi. str. 814. - 5. Dtto nad ref. J. Ochorowicza: O promieniach sztywnych i O promieniach XX. str. 836. - 6. Dtto nad ref. M. Stefanowskiej: Doświadczalne badania nad psychologią bólu. str. 838. - 7. Dtto nad ref. J. Lewkowicza: Problemat stosunku ducha do ciała ze stanowiska teorii poznania. str. 845). - 125. GŁOS W DYSKUSJI nad odczytem R. NUSBAUM-HILAROWICZOWEJ: Myślenie zwykłe i naukowe, wygłoszonym na 88. pos. naukowym PTF, 6. 11. 1909. - PF XIII ('10). str. 371. - 126. Przemówienie wygłoszone na VI Zw. Walnym Zgromadzeniu PTF, 12. 2. 1910, W SPRAWIE ZMNIEJSZENIA ILOŚCI GODZIN NAUKI PROPEDEUTYKI FILOZOFII $w$ gimnazjach. $-\mathrm{M}$, XXVI ('10). I. str. 332. Zob. też GLw. nr 36 z 16. 2. '10, str. 3. - SłP nr 72 z 13. 2. '10, str. 3. - 127. GŁOS W DYSKUSJACH nad referatami wygłoszonymi na IV. MIĘDZYNARODOWYM ZJEŹDZIE PSYCHOLOGII EKSPERYMENTALNEJ w Insbruku, 19-22. 4. 1910. (Po niemiecku). - Bericht über den IV. Kongress experimentelle Psychologie. Lg, 1911. (1. Głos w dyskusji nad referatem O. Lipmanna: Visuelle Auffassungstypen. str. 201. - 2. Dtto nad ref. G. F. Lippsa: Mass oder Zahl. Tamże, str. 249. - 3. Dtto nad ref. K. Bühlera: Ein Verfahren zur Untersuchung des Gedächtnisses für räumliche Beziehungen. str. 255). - 128. Przemówienie dziękczynne (Przewodniczącego PTF) z okazji uczczenia jego zasług na 100. POSIEDZENIU POLSKIEGO TOWARZYSTWA FILOZOFICZNEGO. - M, XXXVI ('10), t. II. str. 442-43. (str. 6-7 Odbitki - zob. niżej nr 181*). - PF, XIV ('11). str. 136-7. [Zob. też SłP nr 515 z 6. 11. '10. str. 1-2]. - 129. POWITANIE imieniem PTF. SEKCJI FILOZOFICZNEJ XI. Zjazdu lekarzy i przyrodników polskich w Krakowie, 18-22. 7. 1911. - Księga Pamiątkowa tegoż Zjazdu, str. 83-4. - 130 GŁOS W DYSKUSJI nad odczytem J. Wł. DAWIDA: O spornych kwestiach z zakresu tzw. intuicji, wygłoszonym na 123. pos. naukowym PTF, 17. 2. 1912. - SłP nr 84 z 20. 2. '12, str. 6. - 131. DTTO nad odczytem I. MYŚLICKIEGO: Sprawa początków dziejów filozofii, wygłoszonym na II. Polskim Zjeździe Filozoficznym. - PF, XXXI ('28). str. 63. - 132. ZAGAJENIE KONFERENCJI W SPRAWIE NAUCZANIA PROPEDEUTYKI FILOZOFII we Lwowie, dn. 31. 10. 1931. - RF, XII ('30-31), str. 269 a-b. [Zob. też artykuły objęte nrem $203^{*}$, podające krótkie streszczenia przemówienia dziękczynnego po otrzymaniu tytułu doktora honoris causa Uniwersytetu Warszawskiego, dn. 14. 2. 1929].

\section{VARIA.}

133. AFORYZMY O KIERUNKACH ETYCZNYCH. - Jednodniówka wydana przez Koło im. Kazimierza Wielkiego Twa Szkoły Ludowej, 
1903. (Jednodniówki tej nie udało się dotąd odszukać. Wiadomość o jej ukazaniu się oparta jest na zapiskach, zawartych w spuściźnie rękopiśmiennej) - 134. WSTĘP do polskiego przekładu Dra J. VAIHINGERA „Filozofia Nietzschego". Lw., '04. str. 1-2. Zob. niżej nr 214. - 135. OD TŁUMACZY. 1. do I. wydania przekładu HUME'A Badań dotyczących rozumu ludzkiego. [Zob. niżej nr 213]. Lw., 1905. str. 247-8. - Pdr.: w II. wydaniu, str. 200. - Dtto w III. wydaniu. str. 200-01. (Wspólnie z J. Łukasiewiczem). - 2. Do drugiego wydania. Tamże. II. wydanie. Lw., 1919, str. 201. - Pdr. w III. wyd. str. 201. - 3. Do trzeciego wydania. Tamże. III. wydanie. Lw., 1928. str. 201. - 136. KONKURS DLA STUDENTÓW FILOZOFII. - RF, VI (1921/22). str. 115-6. - 137. PRZEDMOWA do polskiego przekładu odczytu O ISTOCIE POJĘĆ (Lw., 1924), str. V-VII. Zob. powyżej nr 67 i poniżej w dziale „Przekłady”.

\section{PODRĘCZNIKI}

138. ZASADNICZE POJĘCIA DYDAKTYKI I LOGIKI DO UŻYTKU W SEMINARIACH NAUCZYCIELSKICH I W NAUCE PRYWATNEJ. Lw., nakładem Twa Pedagogicznego, 1901, Str. 224. XVI. 19,5 $\mathrm{x} 14$.

[Rec.: 81 . Pechnik A. Ks. - PPw. XVIII. t. 72 ('01). str. 410-7. - 82*. A. - Pogląd na Świat, Kr., '02, str. 322-4. - 83 a*. Szycówna A. - Ks., II ('02). str. 233-4. - 83 b*. Szycówna A. - PPed. XXI ('02). str. 160-1].

139. O FILOZOFII ŚREDNIOWIECZNEJ WYKŁADÓW SZEŚĆ. Lw.Wwa, H. Altenberg, 1910. Str. 12 nl. 138. 20 x 15. - Pdr. stron: 4-8, 40$45,49-50,52-3,61-2,81,82-3$ pt. Historia sporu o universalia w wiekach średnich w książce A. K., str. 267-276. - 140. AUTOREFERAT nru 139. - PF, III ('10). 1-2, str. 250-1. - 141. Autoreferat niemiecki pt. SECHS VORLESUNGEN UEBER DIE MITTELALTERLICHE PHILOSOPHIE. - PhG. III ('11). p. 58-9.

[Rec.: 84*. Borowski M. - Na Ziemi Naszej, dodatek do KLw., II ('10). 7. str. 51-2. - 85*. Myśl Niepodległa, 1910, nr 129, str. 425-426. - 86*. Gabryl Fr. Ks. - PPw. CV ('10). str. 387-91. - 87*. Matzel E. Ks. Z powodu książki o filozofii średniowiecznej. - PP., CVII ('10). str. 153172. (Także w odbitce. Kr., Str. 22. Broszury o chwili obecnej. Zesz. 27). - 88*. Sob. - SłP nr 167 z 12. 4. '10, str. 2-3. - 89*. Wais K. Ks. W obronie scholastyki. (Z powodu książki o filozofii średniowiecznej). - Gazeta Kościelna, XVIII ('10). nr 10, str. 122-4; 12, 146-7; 13, 163-4; 15, 186- 8; 16, 203-5. (Także w odbitce. Lw., '10, Str. 35). - 90*. Zieleńczyk A., Z literatury filozoficznej. - Krt., XII, [na karcie tytułowej przez omyłkę wydrukowano: XI], czerwiec'10. str. 361-3. -91*. Rodzina i Szkoła, XV ('10). str. 122-3. - 92*. Haliński T. - Tygodnik 
Polski, Wwa, II ('13). 5. str. 79. - 93*. Schmidt W. - PPed., XXII ('13). 4. str. 14-16. - Zob. też Halpern, str. 556 i Tenże, AGPh. str. 383].

\section{SPRAWOZDANIA}

\section{SPRAWOZDANIA KRYTYCZNE [RECENZJE]}

142. Brentano Fr. Ueber die Zukunft der Philosophie. W, 1893. - OeL. II (1893). p. 357-8. - 143. Hausegger Fr. Das Jenseits des Künstlers. Fremden - Blatt, 9. 6. 1893. - 144. Pechnik A. O reformie tzw. propedeutyki filozofii. Tarnów, 1892. - OeL. II (1893). p. 647. - 145. Resl W. Das menschliche Ich. Lemberg, 1892.- Tamże. - 146. Kiefl Fr. Pierre Gassendis Erkenntnistheorie. Fulda, 1893. - OeL. III (1894). p. 295. 147. Jaesche E. Seele und Geist in streng wissenschaftlicher Auffassung. Lg, 1893. - Tamże p. 648. - 148. Skorski A. Filozofia jako nauka akademicka. - A, LXXVI (1894). 4. str. 171-5. - 149. Tenże. Dtto. PPA, XIX (1895). str. 391-5. [Nie jest identyczne z nrem 148. Zajmuje się specjalnie rozdziałem IV omawianej książki, poświęconym filozofii nauk moralnych]. - 150. Gerber G. Das Ich als Grundlage unserer Weltanschauung. Brl., 1893. - OeL. IV (1895). p. 47-8. - 151. Gutberlet C. 1. Die Willensfreiheit und ihre Gegner. Fulda, 1893. - 2. Der mechanische Monismus. Paderborn, 1893. - Tamże, p. 112-3. - 152. Kreibig J. Cl. Seelenwanderungen. Dresden. - Tamże, p. 197. [Recenzja niepodpisana] - Autentyczność stwierdzona na podstawie informacji udzielonych przez K. Twardowskiego Dr H. Słoniewskiej). 153. Bergmann J. Geschichte der Philosophie. Brl., 1892-3. - Tamże, p. 335-6. - 154. Carneri B. Empfindung und Bewusstsein. - Tamże, p. 559-60. - 155. Weygandt W. Entstehung der Träume. Eine psychologische Untersuchung. Lg, 1893. - Tamże, p. 560. - 156. Deichmann K. Das Problem des Raumes in der griechischen Philosophie bis Aristoteles. Lg, 1893. - Tamże, p. 589. - 157. Uphues G. K. Psychologie des Erkennens. Lg, 1893. - Vossische Zeitung. Sonntagsbeilage. Nr 22 z 2. 6. 1895. str. 3-6. - 158. 1. Deussen P. Allgemeine Geschichte der Philosophie mit besonderer Berücksichtigung der Religionen. T. I. Lg, 1894. - 2. Garbe R. Samkhya-Philosophie. Lg, 1894. - 3. Straszewski M. Historia filozofii wschodniej. Kr., 1894. - Wiener Zeitung, nr 258 z 6. 11. 1895, str. 2-4 i Nr 259 z 7. 11. 1895, str. 2-5. - 159. NOWE KSIĄŻKI O FILOZOFII WSCHODU. 1. Deusen P., Garbe R. i Straszewski M. jw. - Prz. 1896, str. 22-32. - 160. Lipps Th. Grundzüge der Logik. Hamburg u. Lg, 1893. - OeL. V (1896). p. 102. - 161. Cornelius H. Versuch einer Theorie der Existentialurteile. Munchen, 1894. - Tamże, p. 230-1. - 162. Brentano Fr. Die vier Phasen der Philosophie und ihr augenblicklicher Stand. Stuttgart, 1895. - Tamże, p. 295. - 163. Erdmann B. Grundriss der Geschichte der Philoso- 
phie. - Tamże, p. 328-9. - 164. Elsenhans Th. Eine Psychologie der Ethik. Lg, 1894. - Przewodnik Naukowy i Literacki, Lw. XXIV (1896). str. 569-74. - 165. Pechnik A. Ks. Zarys psychologii. - M, XII (1896). 5. str. 282-90; 369-379. - 94*. Pechnik A. Ks. Odpowiedź na recenzję mojego Zarysu psychologii, zamieszczoną w Muzeum, str. 282 sqq. i 369 sqq. - Tamże, str. 634-41. - 95*. Tenże. Odpowiedź na zarzuty Szanownych pp. Recenzentów uczynione mojemu podręcznikowi. [Lw., 1896], str. 8. [Dotyczy tylko cz. I. oceny powyższej K. Twardowskiego i prawie wyłącznie tej oceny], - 166. ODPOWIEDŻ DRA K. TWARDOWSKIEGO. - M, XII (1896). str. 642-4. - 167. Höfler A. Die metaphysischen Theorien von den Beziehungen zwischen Leib und Seele. - OeL. VI (1897). 13. str. 391-3. - 168. Höfler A. Psychologie. W, 1897. - 2. Sieben Thesen zu Prof. Dr Fr. v. Liszt's Vortrag: Die strafrechtliche Zurechnungsfähigkeit. W, 1897. - Tamże, p. 393. - 169. Höfler A. Psychologie. W, 1897. - Przewodnik Naukowy i Literacki, XXVI (1897). str. 661-70. - 170. NOWA POLSKA KSIĄŻKA O FILOZOFII. (H. Struve: Wstęp krytyczny do filozofii). - PP, XXXII (1897). t. 123. str. 533-556. (Także w odbitce. Kr., 1897, Str. 24. 22,5 x 15). - 171. Thomas H. Suggestia w wychowaniu. Przekład A. Solickiej. - Szkoła, Lw., 1898, str. 298. - 172. Tezner Fr. Politische Bildung und Patriotismus. - PPA, XXIII (1898). str. 585-90. - 173. Przegląd Filozoficzny, I. 3. - Życie, Kr. II (1898). 32. str. 422-3. - 174. Abramowski E. Teoria jednostek psychicznych. Wwa, 1899. - PF, III (1900). 1. str. 63-79. 175. Paulsen Fr. Philosophia militans. Brl., 1901. - Tygodnik Słowa Polskiego, 1902, nr 1 z 6. 7, str. 6 i nr 2 z 13. 7, str. 7. - 176. Żuławski J. Benedykt Spinoza, człowiek i dzieło. Wwa, 1902. - Tamże, nr 5. z 3. 8, str. 7-9. - 177. Schopenhauer A. Rozprawa konkursowa o podstawie moralności. Przekład Z. Bassakówny. Wwa, 1901. - PF, VII ('04). 1. str. 79-87. - 178. Kozłowski Wł. M. Historia filozofii. Cz. I. do końca XVIII w. Wwa, '04. - PF, VIII ('05). 2. str. 156-60. - 179. ODCZYTY OXFORDZKIE BERGSONA. [Rec.: Bergson H., La perception du changement. London, '11]. - SłP nr 584 z 15. 12. '11, str. 1-2 i nr 585 z 16. 12. '11, str. 1-2. - 180. Bergson H. La perception du changement. London, '11. - RF, II ('12). str. 5b-6 a. -181. Bibliographie pédologique polonaise, redigée par Mlle A. Szyc. Varsovie, 11. - M, XXVIII ('12). t. I. str. 124-9. - 182. Wize K. F. Wykłady filozoficzne. Poznań, '16. - RF, IV ('14-18). str. 240 a-243 b. - 183. Claparède E. La psychologie de l'intelligence. - RF, V ('19). str. 128 b-130 a. - 184. Demianowski A. Badania eksperymentalne nad uwagą telegrafistów kolejowych jako przyczynek do psychologii życia gospodarczego. RF, VII ('22). str. 82 a-84 a. - 185. Halpern I. Stanowiska w etyce. Wstęp metodologiczny do etyki. - Tamże, str. 101 b-105 a. - 186. Reichls Philosophischer Almanach auf das Jahr 1923. - RF VIII ('23). str. 6 a-7 a. 


\section{SPRAWOZDANIA REFERUJĄCE}

187. Mind. N. S. Nr 21. - Vierteljahrsschrift f. wissenschaftliche Philosophie. XXI. 1. 2. - PF I (1897/8). 1. str. 141-7. - 188. Mind. N. S. Nr 22 i 23. - Vierteljahrsschrift jw. XXI. 3. - Tamże, 3. str. 125-31. - 189. Mind N. S. Nr 24. - Vierteljahrsschrift jw. XXI. 4. (Sprawozdanie niepodpisane. Autentyczność potwierdzona przez nr 200, str. XXVI s. v. Twardowski). - PF, II, 1898/9. 1. str. 129-32. - 190. Mind. N. S. Nr 29 i 30. - PF, III (1900). 2. str. 114-9. - 191. Vierteljahrsschrift jw. XXIII. 1. - Tamże, 3. str. 132-7. - 192. Waldapfel J. Persönliche Energie. (Annalen der Naturphilosophie, V. 13. lipiec 1906). - PF. X ('07). str. 126-7. - 193. Streszczenie rozprawy A. Stögbauera „Teoria funkcyj psychicznych a psychologiczna analiza", nadesłanej przez autora a streszczonej i częściowo odczytanej na 87. pos. naukowym PTF 6. 7. '09, przez K. Twardowskiego. - PF, XII ('09). str. 565-6. 194. Streszczenie rozprawy R. Ingardena: O pytaniach essencjalnych (Autentyczność poświadczona przez Autora referowanej rozprawy). - Sprawozdania Twa Naukowego we Lwowie, IV ('24). str. 119-35. - 195. VI. Międzynarodowy Zjazd Filozoficzny (Artykuł niepodpisany). - RF XI ('28/9). str. 5-16. - 196. Streszczenie rozprawy Blausteina L.: Husserlowska nauka o akcie, treści i przedmiocie przedstawienia (Autentyczność poświadczona przez Autora referowanej rozprawy). - Sprawozdania Twa Naukowego we Lwowie, VIII ('28). str. 8-13. Lw., '29.

\section{PUBLIKACJE O CHARAKTERZE INFORMACYJNYM}

197. Dr KAZIMIERZ TWARDOWSKI. - Kronika Uniwersytetu lwowskiego, I (1894/5 - 1897/8). Lw., 1899. str. 210-211. - 198. RUCH FILOZOFICZNY WE LWOWIE. (Artykuły niepodpisane. Autentyczność stwierdzają zapiski zawarte $\mathrm{w}$ spuściźnie rękopiśmiennej). - PF V ('02). str. 359-61; VI ('03). str. 113-4. - 199. LIST OFICJALNY DO REDAKCJI PRZEGLĄDU FILOZOFICZNEGO. - PF, VII ('04). str. 104. [Zob. Strusiński W.: Przegląd ruchu filozoficznego. - Krt. VI ('04). I. str. 86]. - 200. SPIS AUTORÓW I SZCZEGÓŁOWY INDEKS TREŚCI ZAWARTEJ W PIERWSZYCH DZIESIĘCIU ROCZNIKACH PRZEGLĄDU FILOZOFICZNEGO. (Bez podpisu, zob. jednak poniżej nry 203 i 206, gdzie ten Spis rzeczy przytoczony jest przez K. Twardowskiego wśród jego prac). Wwa, '07, str. XXI-XCIV. - 201. Streszczenie ZAGAJENIA 100. POSIEDZENIA PTF (4. 11. 1910). RF, I ('11). str. 52 a. - 202. SPRAWOZDANIA Z OBRAD SEKCJI FILOZOFICZNEJ XI ZJAZDU LEKARZY I PRZYRODNIKÓW POLSKICH. - RF, I ('11). str. 161-7. - 203. DR. KAZIMIERZ TWARDOWSKI. - Kronika Uniwersytetu lwowskiego, II (1898/9 - 1909/10). 
Lw., '12. str. 503-510. - 204. Odpowiedzi Redakcji: 1. Novum Organum Bacona. - RF, III ('13). str. 256 b. - 2. Rozumnik. - Tamże. - 205. Odpowiedź Redakcji: Podświadomość. - Tamże, str. 288 b. - 206. TWARDOWSKI ZE SKRZYPNY KAZIMIERZ JERZY ADOLF. Dane bio- i bibliograficzne. - Sprawozdania Twa Naukowego we Lwowie, II ('21). 2. str. 145-9. - 207. I. POLSKI ZJAZD FILOZOFICZNY (Artykuł niepodpisany). - RF, VII ('22/23). - str. 81-2. - 208. ZAGAJENIE XIX ZW. WALNEGO ZGROMADZENIA PTF, 12. 2. 1924 [w 20. rocznicę założenia Twa]. - RF, VIII ('23/24), str. 91 b - 92 a. - 209. GŁOSY W SPRAWIE SŁOWIAŃSKIEGO ZJAZDU FILOZOFICZNEGO. (Artykuł niepodpisany). - RF, IX ('25). str. 1-6. - 210. WSTĘP DO KSIĘGI PAMIĄTKOWEJ I POLSKIEGO ZJAZDU FILOZOFICZNEGO. PF, XXX ('27). str. 255-8. - 211. II POLSKI ZJAZD FILOZOFICZNY. (Artykuł niepodpisany. - RF, X ('26/7). str. 15-6. - 212. PO II POLSKIM ZJEŻDZIE FILOZOFICZNYM. (Artykuł niepodpisany). - RF, X ('26/27). str. 93-7. - 213. III. POLSKI ZJAZD FILOZOFICZNY. - RF, XIII 5-10 ('37). str. 71-5.

\section{PRZEKŁADY}

\section{PRZEKŁADY WŁASNE}

214. Vaihinger J. Dr. Filozofia Nietzschego. Z 2. wyd. oryginału przełożył z upoważnienia Autora Dr K. T. AL - WW. '04. Str. 94. (Wiedza i Życie, III. 1).

[Rec. dotyczące też przekładu: 96*. Strusiński W. - Krt. VI ('04). II. str. 380-381. - 97*. Tenże. - SłP nr 349 z 26. 7. '04, str. 1-2].

215. Hume D. Badania dotyczące rozumu ludzkiego, (wspólnie z J. Łukasiewiczem). Lw., PTF, '05, Str. 240. - 2. wyd. '19. Str. 201. - 3. wyd. '28. Str. 202. - Pdr. stron: 34-9 i 51-2 wydania 2. pt. „Wnioski o faktach i stosunek przyczynowy" w książce: A. K. str. 90-96.

[Rec. [dotyczące też przekładu]: 98*. 1. Strusiński W. Dawid Hume. - SłP nr 362 z 5. 8. '05, str. 1-2]. 2. Ginsberg E. - PH, V ('30). str. 205-6].

216. Fullerton G. St. Neorealizm amerykański. - RF IV ('14-18). str. 142-4 .

[67]. O istocie pojęć. Przekład własnego odczytu pt. Ueber begriffliche Vorstellungen. Zob. powyżej nr 67.

217. Cay v. Brockdorff, rec. Łubieński Zb., Die Grundlagen des ethischpolitischen Systems von Hobbes. - RF, XIII. 5-10 ('37). str. 97 a-98 a.

\section{REDAKCJE PRZEKŁADÓW CUDZYCH}

218. Külpe O. O zadaniach i kierunkach filozofii. Z niemieckiego przełożyli z upoważnieniem Autora członkowie „Kółka filozoficznego" 
pod redakcją Prof. Dra K. T. Tom. I. II. AL-WW, 1899. (Wiedza i Życie, R. I. t. 5 i 7). - 2. wyd. [1910?]. (Nie udało się dotąd ustalić, czy wspomniane 2. wydanie istotnie ukazało się w druku. Przypuszczenie, że tak było, oparte jest na dwóch faktach: 1. w katalogu kartkowym Biblioteki Uniwersyteckiej we Lwowie znajduje się kartka, rejestrująca tom I. wydania 2. Lwów, (1910). H. Altenberg, Str. VIII. 132. [Tom I. w wydaniu 1. liczy stron VIII. 121. 3 nl.]. Egzemplarz skatalogowany na tej kartce zaginął, podobno jeszcze przed r. 1914. - 2. W spuściźnie rękopiśmiennej K. Twardowskiego zachowała się Przedmowa do drugiego wydania, z daty 1908 r. - Zob. powyżej nr 29.

[Rec. (dotycząca częściowo też przekładu): Bizoń Fr. - SłP nr 203 z 26. 8. 1899. str. 4].

219. Fechner G. Th. Książeczka o życiu pośmiertnym. Z 6. wyd. niemieckiego przełożył B. Maczewski. Przekład przejrzał i wstępem zaopatrzył K. T. AL - WW, '07, Str. 114.

220. Tenże. O zagadnieniu duszy. Wędrówka przez świat widzialny ku niewidzialnemu. Wyd. 2. Do druku przygotował Dr E. Spranger. Na język polski przełożyła Dr Z. z Pasławskich Drexlerowa. Przekład przejrzał i wstępem zaopatrzył K. T. AL - WW, '21, Str. X. 296.

\section{DZIAŁALNOŚĆ REDAKCYJNA}

Kazimierz Twardowski był od chwili, gdy zaczął w Warszawie wychodzić „Przegląd Filozoficzny” tj. od r. 1897 do końca życia, a zatem przez lat z górą czterdzieści lwowskim przedstawicielem Redakcji tego pisma. Wchodził też w skład sądów rozpisanych przez „Przegląd Filozoficzny" w latach 1904, 1907, 1911 i 1920 konkursów naukowych. - Od chwili powstania Polskiego Towarzystwa Filozoficznego (1901) redagował wszystkie wydawnictwa wychodzące nakładem tego Towarzystwa; w redagowaniu czasopisma "Studia Philosophica” współdziałali z nim Kazimierz Ajdukiewicz i Roman Ingarden. - W latach 1911-14 wchodził w skład Komitetu Redakcyjnego wydawanej w Warszawie „Neurologii Polskiej". - Od r. 1911 do końca życia wydawał i redagował (z przerwą 1915-17, spowodowaną wypadkami wojennymi i obowiązkami rektorskimi) „Ruch Filozoficzny”. - W r. 1912 stworzył redakcję polskiego działu Międzynarodowej Bibliografii filozoficznej „Die Philosophie der Gegenwart”, wydawanej pod kierunkiem A. Rugego w Heidelbergu; na czele tej Redakcji stał aż do wybuchu wielkiej wojny. - Zredagował „Księgę Pamiątkową I. Polskiego Zjazdu Filozoficznego”, która ukazała się jako z. 4. tomu XXX (1927) "Przeglądu Filozoficznego". - Od r. 1935 wchodził w skład Komitetu Redakcyjnego Międzynarodowego wydawnictwa Monografij psychologicznych ukazującego się w Amsterdamie pt. „Acta Psychologica”. 


\section{B. Prace niefilozoficzne}

\section{PRACE ORYGINALNE}

\section{ROZPRAWY}

221. DIE UNIVERSITÄT LEMBERG. Materialien zur Beurteilung der Universitätsfrage. Wien, Selbstverlag des Verfassers, 1907, Str. 21. 22 $x$ 28. -

222. SMUTNE REFLEKSJE. (Rzecz niepodpisana). - M, XXV ('09 . I. str. 3-19. - Pdr.: MR, str. 220-237.

223. W SPRAWIE UNIWERSYTETU LWOWSKIEGO. - M, XXIV ('08). II. str. 189-219. (Rzecz niepodpisana). Także w odbitce pt. „W sprawie uniwersytetu lwowskiego. Głos TNSW". Lw., nakładem TNSW, '08, Str. 31.23 x 15). - Pdr.: MR, str. 185-219.

224. KILKA UWAG O SPRAWIE SZKOLNEJ W KRÓLESTWIE. - SłP nr 192 z 24. 4. '08, str. 3-4 i nr 194 z 25. 4. '08, str. 3-4. Powtórzone w M, XXIV ('08). II. str. 99-108, pt. „W sprawie abiturientów szkół polskich w Królestwie". (Także w odbitce. AL.-WW, '08, Str. 13. 24 x 16). - Pdr.: MR, str. 174-184.

[Rec.: 99*. SłP nr 458 z 1. 10. '08, str. 9].

225. PRZECIĄŻENIE. - M, XXVII ('11). I. str. 1-14. - Pdr.: MR, str. 238-52 .

226. W SPRAWIE PROJEKTU USTAWY O USTROJU SZKOLNICTWA. Opinia Wydziału Humanistycznego Uniwersyteu J. K., 1927, str. 24. 23 x 15. (Bez podpisu. Autentyczność poświadczona przez zapiski znajdujące się w spuściźnie rękopiśmiennej).

\section{ROZPRAWY MNIEJSZE I ARTYKUŁY}

227. SUCZAWICA. (Wspomnienia z wycieczki). - GN nr 181 z 10. 8. 1886, str. 1-2. - 228. "SARMATIS PEREGRINANTIBUS SALUS". (Wspomnienia o grobowcu królewskim). - GN nr 242 z 22. 10. 1886, str. 1-2. - 229. KAMIEŃ. (Z wycieczki archeologicznej). - GN nr 270 z 25. 11. 1886, str. 1. - 230. SUCZAWICA, DAS KLOSTER DER „SCHWARZEN MÖNCHE”. - Local-Anzeiger der „Presse” Wien, Beilage zu Jahrg. XL. Nr 190 z 12. 7. 1887, str. 9-10. - 231. AUS DER VERGANGENHEIT DER KAISER-FRANZENS-UNIVERSITÄT IN LEMBERG. - Akademische Revue, München, II (1896). 8. str. 4624. - 232. O ŁACINIE I GRECE. - Tygodnik Słowa Polskiego, Lw., '02, nr 16, str. 6-8. - 233. KRONIKA UNIWERSYTECKA. I. - SłP nr 462 z 1. 10. '04, str. 1-3. - 234. KRAJOWA RADA PEDAGOGICZNA. -M, XXII ('06). II. str. 1-7. - Pdr.: 1. Szkoła, Lw. XXXIX ('06). str. 238-40. - 
2. MR, str. 162-9. - 235. SZKOŁA A WYBORY. - M, XXIII ('07). I. str. 253-5. - Pdr.: MR, str. 170-3. - 236. W SPRAWIE OSTATNIEJ KLASYFIKACJI W LWOWSKICH SZKOŁACH ŚREDNICH. - SłP nr 76 z 14. 2. '08, str. 7-8. - Pdr.: MR, str. 253-5. - 237. TOWARZYSTWO NAUCZYCIELI SZKÓŁ WYŻSZYCH O OSTATNIEJ KLASYFIKACJI. SłP nr 90 z 22. 2. '08, str. 6. - Pdr.: MR, str. 256-7. - 238. KOBIETY NA WYDZIALE FILOZOFICZNYM UNIWERSYTETU LWOWSKIEGO W DZIESIĘCIOLECIU 1897-1907. - Spr. Dyrekcji pryw. gimnazjum żeńskiego im. J. Słowackiego za r. szk. 1907/08. Lw., 1908, str. 3-11. (Także w dobitce. AL - WW, '08, str. 9. 22.5 x 15. - [Rec.: 100*. M, XXVI ('10). I. str. 50]. - 239. W SPRAWIE PRZYSZŁYCH PRACOWNIKÓW NAUKOWYCH. - Tygodnik Ilustrowany. Wwa, LXIII ('22). str. 598-9. - 240. DOTYCHCZASOWA USTAWA AKADEMICKA OWOCEM POROZUMIENIA RZĄDU I UCZONYCH. - IKC nr 18 z 18. 1. '33, str. 4.

\section{WYKŁADY, ODCZYTY, REFERATY}

a) Wykłady, odczyty, referaty drukowane w całości

241. W SPRAWIE EGZAMINU DOJRZAŁOŚCI. Referat wygłoszony na XIX Walnym Zgromadzeniu TNSW 31. 5. '03. - M, XIX ('03). z. 8. Spr. z tegoż WZgr., str. 23-8. - Pdr.: MR, str. 125-41. - Zob. też: Wnioski Wydziału w sprawie egzaminu dojrzałości. Referent Prof. Dr K. T. Punkt IX „Porządku dziennego” XIX. WZgr. TNSW, 31. 5 i 1. 6. '03. - M, jw. z. 5. str. II. - 242. GŁOS W DYSKUSJI nad referatem powyższym. - M, jw. z. 8. Spr. z 19 WZgr. TNSW, str. 55-7.

[Rec.: 101*. TNSW. - Pgl. nr 126 z 4. 6. '03, str. 2. - Zob. też DzP. nr 254 z 3. 6. '03, str. 2. - GLw nr 125 z 3. 6. '03, str. 5. - GN nr 125 z 3. 6. '03, str. 2. - KLw. nr 152 z 3. 6. '03, str. 3. - SłP nr 253 z 3. 6. '03, str. 6; cf. nr 252 z 2. 6. '03, str. 2].

243. WYCHOWANIE I NAUKA. Wykład wstępny. - Spr. z Wakacyjnego Kursu Uniwersyteckiego urządzonego w Cieszynie przez Polskie Two Pedagogiczne w Księstwie Cieszyńskim, dn. 15. - 30. 8. '04. Cieszyn, 1904. str. 6-12. - Zob. też WSTĘP do tegoż wykładu. - SłP nr 387 z 18. 8. '04, str. 2.

244. UNARODOWIENIE SZKOŁY. Przem. wygłoszone na Wiecu rodzicielskim zwołanym w sprawie unarodowienia szkoły przez Komitet pracy narodowej we Lwowie, dn. 18. 11. '05. - M, XXI ('05). str. 885894. - (Także w odbitce., Lw., '05, Str. 10). Pdr.: MR, str. 142-52. [Zob.: Pgl., nr 265 z 21. 11. '05, str. 3. - Zob. też GN nr 266 z 21. 11. '05, str. 3. - KLw. nr 321 z 20. 11. '05, str. 2. - SłP nr 540 z 20. 11. '05, str. 3. - WN nr 1317 z 21. 11. '05, str. 5]. 
245. O OBCHODACH NARODOWYCH. Referat wygłoszony na uroczystym posiedzeniu Koła krakowskiego TNSW ku czci M. Reja, 16. 12. '05. - MST, XXII ('06). I. str. 76-81. - Pdr.: MR, str. 153-61.

246. O KOLONII WAKACYJNEJ TNSW. Referat wygłoszony na XXIV. WZgr. TNSW. 7. 6. '08. - M, XXIV ('08) II. 2. Spr. z tegoż WZgr. str. 13-14. - Cz. nr 131 z 9. 6. '08, str. 1. - Pdr.: Mr, str. 112-3. - [Zob. z 9. 6. '08: Cz. jw.; KLw. nr 267, str. 3. - NR nr 263, str. 1. - Z 10. 6. '08: GLw. nr 132, str. 2; GN nr 133, str. 2. - Pgl. nr 134 z 11. 6. str. 2].

247. W NIEWOLI NIEMIECKIEJ. Referat wygłoszony na zebraniu publicznym w Sali ratuszowej we Lwowie, 6. 12. '08. - SłP nr 577 z 10. 12. '08, str. 1-2 i 579 z 11. 12. '08, str. 2-3. [Zob. z 7. 12. '08: DzP. nr 571, str. 3. - KLw. nr 572, str. 5. WN nr 2229, str. 5].

248. O BIURZE POLSKIEJ STATYSTYKI SZKOLNEJ I OŚWIATOWEJ. Referat wygłoszony na II. Zjeździe członków TNSW, 15. 5. '10. - M, XXVI ('10). II. z. 5. Spr. z II. Zj. Czł. i 26. WZgr., str. 3-12. - GŁOS W DYSKUSJI nad tymże referatem. - Tamże, str. 14-5. - [Zob. Cz., nr 219 z 17. 5. '10, str. 1].

249. O PATRIOTYZMIE. Odczyt wygłoszony na otwarciu Uniwersytetu żołnierskiego we Lwowie, w sali Sokoła Macierzy, 29. 3. 1919. Lw., '19, Str. 24.15 x 20. (Biblioteka Macierzy Polskiej nr 113). [Spr. z odczytu SłP nr 91 z 2. 4. '19, str. 4. - z 3. 4. '19: GLw. nr 77, str. 3; WN nr 5356, str. 9-10. - Rec.: 102*. J. P. - GLw. nr 248 z 26. 10. '19, str. 4. 103*. S. M. Uczony w służbie codziennej. - GW nr 4966 z 5. 12. '19, str. 3].

250. O DOSTOJEŃSTWIE UNIWERSYTETU. Wykład wygłoszony w czasie uroczystej promocji na doktora honoris causa Uniwersytetu poznańskiego w Auli Uniwersytetu J. K., dn. 21. 11. 1932. Poznań, Uniwersytet Poznański, 1933, Str. 18. 21 x 29.

[Spr. 104*. Prof. Dr Porębowicz i Prof. Dr Twardowski doktorami h. c. Uniwersytetu poznańskiego. - Z 23. 11. '32. GLw. nr 273, str. 4. - SłP nr 322, str. 4. - [Rec.: 105*. Łempicki Z. Zagadnienie szkół akademickich w Polsce. - Kurier Polski nr 143 z 27. 5. '34].

b) Wykłady i odczyty drukowane w streszczeniu

$106^{*}$. Czy człowiek pierwotny był podobny do współczesnych nam dzikich? Odczyt wygłoszony w Towarzystwie Ludoznawczym w Sali Muzeum Botanicznego Uniwersytetu. 15. 3. 1900. - SłP nr 131 z 20. 3. 1900, str. 4. - [† Pojęcie wychowania. Wykład wygłoszony na Zjeździe Twa Pedagogicznego we Lwowie, 5. 7. '14. - Wzmianki o treści tego wykładu: DzP nr 179 z 6. 7. '14, str. 3. - GW nr 1960 z 6. 7. '14, str. 5]. 


\section{PRZEMÓWIENIA}

(Pominięte zostały tutaj przemówienia czysto formalne, związane $\mathrm{z}$ tokiem obrad różnych zrzeszeń, zwłaszcza TNSW.)

a) Przemówienia drukowane w całości

251. PRZEMÓWIENIE WYGŁOSZONE NA INAUGURACJI III ROKU [POWSZECHNYCH] WYKŁADÓW (UNIWERSYTECKICH WE LWOWIE), w niedzielę, dn. 3. 11. 1901. Lw., nakładem Autora, 1901, str. 9. 18 x 12. - To samo: KLw. nr 307 z 5. 11. '01, str. 1-2. - [Zob.: GN nr 306 z 4. 11. '01, str. 1. - Z 5. 11. '01: GLw. nr 254, str. 3. - Pgl. nr 255, str. 2. - SłP nr 516, str. 5]. - 252. POWITANIE XXI WALNEGO ZGROMADZENIA TNSW IMIENIEM UNIWERSYTETU LWOWSKIEGO, 11. 6. '05. - M, XXI ('05). listopad, Spr. z tegoż WZgr. str. 1-2. - Pdr.: MR, str. 3-4. [Zob. Z 13. 6. '05: DzP nr 269, str. 11. SłP nr 272, str. 5. - KLw. nr 162 z 14. 6. '05, str. 1]. - 253. Przem. PO WYBORZE NA PRZEWODNICZĄCEGO TNSW, wygłoszone na XXI. Walnym Zgromadzeniu, 12. 6. '05. - M, jw. str. 47-9. - Pdr.: MR, str. 5-8. - [107*. Po Walnym Zgromadzeniu TNSW. - SłP nr 276 z 15. 6. '05, str. 1-2. Zob też DzP, KLw. i SłP jw.]. 254. Przem. NAD TRUMNĄ ŚP. PROF. KALINY, wygłoszone 6. 5. '06. - SłP nr 201 z 8. 5. '06, str. 4-5. - Zob.: Kronika Uniwersytetu lwowskiego. II. Lw., '12, str. 197. - 255. ZAGAJENIE XXII WALNEGO ZGROMADZENIA TNSW, 3. 6. '06. - M, XXII ('06). II. 4. Spr. z tegoż WZgr. str. 3-11. Pdr.: MR, str. 9-19. - [Zob. z 5. 6. '06 Cz. nr 127, str. 1-2; SłP nr 246, str. 5. - Z 6. 6. '06: DzP nr 249, str. 1; GłN nr 268, str. 1-2; NR nr 226, str. 2. - GLw. nr 129 z 7. 6. '06, str. 4]. -256. PODZIĘKOWANIE za uznanie wyrażone na XXII. Walnym Zgromadzeniu TNSW 3. 6. '06. (Por. nr 272*. - M, jw. str. 19. - 257. Przem. PRZED POWTÓRNYM WYBOREM NA PRZEWODNICZĄCEGO TNSW, 4. 6. '06. - Tamże, str. 37-9. - Pdr.: MR, str. 20-22. - 258. Przem. w sprawie utworzenia SEKCJI NAUCZYCIELI SEMINARIÓW w łonie TNSW, wygłoszone tamże. - Tamże, str. 40-41. - 259. Przem. na posiedzeniu WYDZIAŁU TNSW. 26. 1. '07. - MST, XXIII ('07). I. str. 40. - 260. ZAGAJENIE XXIII WALNEGO ZGROMADZENIA TNSW, 19. 5. '07. - M, XXIII ('07), II. 5. Spr. z tegoż WZgr. str. 2-10. - Pdr.: MR, str. 23-33. - [Zob. DzP. nr 233 z 21. 5. '07, str. 1. Z 23. 5. '07: GLw. nr 116, str. 4. - SłP nr 116, str. 4. - Pgl. nr 117 z 24. 5. '07, str. 2]. - 261. Przem. W SPRAWIE ZMIANY STATUTU na Nadzw. Walnym Zgromadzeniu TNSW, 1. 2. '08. - MST, XXIV ('08), I. str. 128-30. - 262. Przem. w sprawie ORGANIZACJI KOŁA LWOWSKIEGO TNSW i jego Zarządu. - Tamże, str. 134. - 263. POŻEGNANIE b. Wiceprezydenta Rady Szkolnej Krajowej, DRA E. PŁAŻKA, wygłoszone 
imieniem deputacji TNSW, 26. 3. '08. - M, XXV ('08). I. str. 423-4. Pdr.: RM, str. 100-1. - 264. PRZYWITANIE Wiceprezydenta Rady Szkolnej Krajowej Dra I. DEMBOWSKIEGO, wygłoszone imieniem jw., 26. 3. '08. - M, jw. str. 425-7. - Pdr.: MR, str. 102-4. - 265. ZAGAJENIE XXIV WALNEGO ZGROMADZENIA TNSW, 7. 6. '08. - M, XXIV ('08). II. 2. Spr. z tegoż WZgr. str. 3-13. - Pdr.: MR, str. 34-47. [Spr.: 108*. Szycówna A.: XXIV. Walny Zjazd TNSW. - Nowe Tory, Wwa, III ('08). str. 334-7. - Zob. też z 9. 6. '08: Cz. nr 131, str. 1. - DzP nr 267, str. 3. - GłN nr 263, str. 1. - KLw. nr 267, str. 2. - NR nr 263, str. 1. - SłP nr 267, str. 5. - Z 10. 6. '08: GLw. nr 132, str. 2. - GN nr 133, str. 2. - Por. też Pgl. nr 134 z 11. 6. '08, str. 2]. - 266. Inne przem. na tymże Walnym Zgromadzeniu. - M, jw. (nr 265), str. 24-5; 32-3; 41-2; 44-5; 47-8; 49-50 i 56. [Zob. przytoczony powyżej artykuł. A. Szycówny, nr 108*]. - 267. PRZYWITANIE Wiceprezydenta Rady Szkolnej Krajowej Dra I. DEMBOWSKIEGO na tymże Walnym Zgromadzeniu, 8. 6. '08. - Tamże, str. 70-1. - Pdr.: MR, str. 105-6. 268. Przem. do DRA E. PŁAŻKA przy sposobności wręczenia mu dyplomu członka honorowego TNSW. - SłP nr 605 z 29. 12. '08, str. 6 („U dra E. Płażka“). - Zob. GN nr 229 z 29. 12. '08, str. 2. - 269. Przemówienie nad grobem śp. Prof. L. PIĘTAKA. - M, XXV ('09). I. str. 247-8. - 270. ZAGAJENIE JUBILEUSZOWEGO ZJAZDU TNSW. 30. 5. '09. - M, XXV ('09). II. str. 4-14. - Pdr.: MR, str. 48-63. - [Zob. 21. 6. '09: DzP nr 272, str. 2. - KLw. nr 251, str. 1. - SłP nr 252, str. 1-2. WN nr 2370, str. 5-6. - Z 2. 6. '09: GLw. nr 123, str. 4-5. - GN nr 124, str. 2. - Pgl. nr 125 z 3. 6. '09, str. 1], - 271. ZAGAJENIE XXV WALNEGO ZGROMADZENIA TNSW, 31. 5. '09. - M, XXV ('09). II. 4. str. 18-22. - Pdr.: MR, str. 64-9. [Zob. GN jw. str. 3]. - 272. Udział w obradach na tymże Walnym Zgromadzeniu. - Tamże, str. 25-6. 273. TOAST na cześć Marszałka Krajowego J. E. ST. HR. BADENIEGO, wygłoszony na bankiecie jubileuszowym TNSW, 30. 5. '09. - M, XXV ('09). II. 4. str. 21-2. - Pdr.: MR, str. 107-8. - 274. TOAST na cześć RADY SZKOLNEJ KRAJOWEJ, wygłoszony tamże. - M, jw. str. 257. - Pdr.: MR, str. 109-11. - 275. ZAGAJENIE NADZWYCZAJNEGO WALNEGO ZGROMADZENIA TNSW, 1. 2. '10. - MST, XXVI ('10). I. str. 87-8. - 276. ZAGAJENIE II ZJAZDU członków TNSW, 15. 5. '10. - M, XXVI ('10). II. 5. Spr. z tegoż Zjazdu i 26. WZgr., str. 3-12. Pdr: MR, str. 70-80. - [Zob. z 17. 5. '10: Cz. nr 219, str. 1. - SłP nr 224, str. 2]. - 277. ZAGAJENIE XXVI WALNEGO ZGROMADZENIA TNSW, 16. 5. '10. - M, jw., str. 47-50. - Pdr.: MR, str. 81-4. - 278. Przem. na uroczystości ROZDANIA ŚWIADECTW DOJRZAŁOŚCI i pożegnania pierwszych abiturientek Pryw. Gimnazjum żeńskiego im. J. Słowackiego we Lwowie, 28. 6. '10. - Spr. Dyrekcji tegoż gimnazjum za r. szk. 1909/10, str. 32-4. - [Zob. M, XXVI ('10). II. str. 216]. - 279. Przem. na II ZJEŹDZIE KIEROWNIKÓW WARSZTA- 
TÓW JORDANOWSKICH, 8. 12. '10. - MST, XXVII (11). I. str. 53-4. [Zob. z 9. 12. '10: KLw. nr 571, str. 3. - SłP nr 570, str. 1. - GLw. nr 280 z 10. 12. '10, str. 6]. - 280. ZAGAJENIE III ZJAZDU członków TNSW, 4. 6. '11. - M, XXVII (11). II. 5. Spr. z tegoż Zjazdu i 27. WZgr. TNSW, 4. 6. '11. - Pdr.: MR, str. 85-95. - [Zob. z 6. 6. '11: KLw. nr 255, str. 2. SłP nr 260, str. 2-3. - GN nr 129 z 7. 6. '11, str. 2]. - 281. ZAGAJENIE XXVII WALNEGO ZGROMADZENIA TNSW, 5. 6. '11. - M, jw., str. 38-41. - Pdr.: MR, str. 96-9. - [Zob. KLw. jw. str. 3. - SłP jw. str. 4]. - 282. MOWA PO ZŁOŻENIU PRZEWODNICTWA W TNSW, 5. 6. '11. - M, jw. str. 54-8. - Pdr.: MR, str. 117-122.

283. Kazimierz Twardowski. MOWY I ROZPRAWY Z OKRESU JEGO DZIAŁALNOŚCI W TNSW. Księga Pamiątkowa, wydana przez TNSW. Zredagował Dr K. Zagajewski. Lw. TNSW, 1912, str. 257. 25 x 18. Zawiera niniejszej Bibliografii nry: 252, 253, 255, 257, 260, 265, 270, 271, 276, 277, 280, 281, 263, 264, 267, 273, 274, 246, 248, 282, 241, 244, 245, 234, 235, 224, 223, 222, 225, 236, 237.

[Rec.: 109*. I. W. K. - KW, nr 192 z 14. 7. '13. str. 3-4. - 110*. Szycówna A. - Ks., XIII ('13). str. 255-7].

284. ZDROJOWISKA NA MACIERZ SZKOLNĄ. Przemówienie na Wiecu Macierzy Szkolnej Księstwa Cieszyńskiego w Zakopanem, 21. 8. 1912. - SłP nr 393, z 24. 8. '12, str. 1-2. [Zob. tamże nr 391 z 23. 8. '12, str. 1-2. - K. W. nr 235 z 25. 8. '12, str. 7]. - 285. SCIENTIA VITAE MAGISTRA. Przemówienie na otwarciu Kursu uzupełniającego dla nauczycieli szkół średnich w Wiedniu, 27. 3. '15. - Szkoła Polska, W, nr 2 z 15. 4. '15, str. 1-4. - [Zob. Nowa Reforma, Kr., nr z 20. 4. '15. - WKP nr 170 z 23. 4. '15, str. 4]. - 286. POWITANIE Namiestnika Bar. DILLERA imieniem Reprezentacji Uniwersytetu lwowskiego we Lwowie, 5. 5. '16. - DzP. nr 226 z 10. 5. '16, str. 2. - GLw. nr 108 z 11. 5. '16, str. 3. - GP nr 2887 z 9. 5. '16, str. 4. - KLw. nr 234 z 9. 5. '16, str. 5. - 287. Przem. [Rektora] na promocji ARCYKSIĘCIA FRYDERYKA na doktora honoris causa Uniwersytetu lwowskiego w siedzibie Naczelnej Komendy Armii. - Z 13. 5. '16: GLw. nr 110, str. 3. - WN nr 4483, str. 3. - 288. Zagajenie AKADEMII KU CZCI SIENKIEWICZA w Auli Uniwersytetu lwowskiego, 20. 12. '16. Z 20. 12. '16: GLw. nr 2897, str. 4. - KLw. nr 637, str. 2-3. - GP nr 3299 z 21. 12. '16, str. 3-4. - [Zob. też WN nr 4674 z 23. 12. '16, str. 5]. - 289. POWITANIE PREZYDENTA RUTOWSKIEGO imieniem Komitetu T. Rutowskiego na dworcu lwowskim, 1. 2. '17. - Z 2. 2. '17: GLw. nr 262, str. 5. - GP nr 3370, str. 2. - KLw. nr 57, str. 7. - WN nr 4709 z 3. 2. '17, str. 2. - Przekład niemiecki: Polen, W, IX ('17). nr 112, str. 199. - 290. Przem. imieniem tegoż Komitetu wygłoszone na UROCZYSTYM PRZYJĘCIU DRA T. RUTOWSKIEGO na Ratuszu lwowskim, 2. 2. '17. - KLw. nr 58 z 3. 2. '17, str. 3-4. - WN nr 4711 z 6. 2. '17, str. 4. - [Zob. też Tamże nr 4710 z 4. 2. '17, str. 6. - GP nr 3372 
z 3. 2. '17, str. 2-3]. - 291. Przem. U TRUMNY ŚP. PROF. J. NUSBAUMA-HILAROWICZA. - Z 17. 3. '17: GW nr 3345, str. 5. - KLw. nr 130, str. 4-5. - 292. Przem. wygłoszone na uroczystości w lwowskim DOMU AKADEMICKIM IM. A. MICKIEWICZA, 22. 4. '17. KLw. nr 194 z 25. 4. '17, str. 2-3.

\section{b) Przemówienia drukowane w streszczeniach}

$111^{*}$. Przem. na Inauguracji IV. r. Powszechnych Wykładów Uniwersyteckich, 9. 11. '02. - Pgl. nr 259 z 11. 11. '02, str. 3. - SłP nr 543 z 11. 11. '02, str. 4. - 112*. Głos w dyskusji na Walnym Zgromadzeniu Twa Gimnazjum żeńskiego, 13. 1. '05. - SłP nr 24 z 14. 1. '05, str. 4. - 113*. Głos w dyskusji nad referatem K. Zagajewskiego „O potrzebie zaprowadzenia nauki nadobowiązkowej języka łacińskiego w szkołach realnych", wygłoszonym na pos. Koła lwowskiego TNSW, 24. 3. '06. - MST, XXII ('06). I. 4. str. 84. - $114^{*}$. Głos w dyskusji w sprawie naruszenia wolności słowa i godności stanu nauczycielskiego na WZgromadzeniu Koła krakowskiego TNSW, 13, 1. '06. - MST, XXII ('06). II. str. 18. - $115^{*}$. Zagajenie pogadanki na temat trwania wakacji letnich w wschodniej części kraju na pos. Koła lwowskiego TNSW, 28. 9. '06. - MST, XXII ('06). II. 3. str. 81. - 116*. Głos w dyskusji nad referatem K. Lutosławskiego pt.: „Rola ogniska wychowawczego wiejskiego" w ogólnym systemie szkolnictwa narodowego, wygłoszonym tamże, 9. 11. '06. - Tamże, str. 143. - 117*. Przem. na Nadzwyczajnym Walnym Zgromadzeniu TNSW, 2. 11. '06. - MST, XXIII ('07). I. str. $2 ; 4 ; 6$. - 118*. Przem. na pos. Wydziału TNSW, 20. 1. '07. Tamże, str. 38-9. - 119*. Przem. na Zjeździe delegatów Austriackiego Twa Szkoły średniej w Pradze, 18 i 19. 11. '06. - Tamże, str. 44. - 120*. Zagajenie posiedzenia Koła lwowskiego TNSW w sprawie projektu nowego statutu Twa (Autoreferat?). - MST, XXIII ('07). I. str. 126-7. 121*. Przem. w toku obrad 23. WZgromadzenia TNSW, 19. i 20. 5. '07 [z wyjątkiem przem. nr 260]. - M, XXIII ('07). z. 5. Spr. z tegoż WZgr. str. 37-8; 38; 44; 52; 63-64; 68; 69-70. - 122*. Przem. imieniem TNSW na otwarciu ogólnoaustriackiego Zjazdu nauczycielskiego we Lwowie, 1. 11. '07. - Z 2. 11. '07: DzP nr 513, str. 1. - SłP nr 510, str. 3. (por. nr 511, str. 7). - WN nr 1899* str. 5. - 123*. Wniosek w sprawie egzaminu dojrzałości, uchwalony na IV. Zjeździe delegatów Austrjackiego Twa szkół średnich we Lwowie, 1. i 2. 11. '07. - MST, XXIV ('08). I. str. 55. $-124^{*}$. Przem. w sprawie stanowiska języka ojczystego w nauce szkolnej, na pos. Koła lwowskiego TNSW, 21. 3. '08. - MST, XXIV ('08). I. str. 110. - 125*. Przem. tamże w sprawie udziału Koła w najbliższym WZgromadzeniu, 16. 5. '08. - Tamże, II. str. 22. - Głos w dyskusji nad tą sprawą. - Tamże, str. 23. - 126*. Głos w dyskusji nad odczytem Dra L. Bykowskiego "Ćwiczenia praktyczne w na- 
ukach przyrodniczych z szczególnym uwzględnieniem biologii", wygłoszonym na pos. Koła lwowskiego TNSW, 28. 11. '08. - Tamże, str. 116-7. $-127^{*}$. Przem. w toku obrad 25. WZgromadzenia TNSW [z wyjątkiem przemówień 271 i 272]. - M, XXV ('09). II. 4. Spr. z tegoż WZgr. str. 22; 33. - 128*. Głos w dyskusji nad referatem H. Orszy (Radlińskiej) „Podstawy wychowania narodowego”, wygłoszonym na 2. Polskim Kongresie Pedagogicznym we Lwowie, 1. 11. '09. Księga Pamiątkowa tegoż Kongresu, Lw., b. d., str. 69. [Zob. z 2. 11. '09: DzP nr 493, str. 3. - SłP nr 511, str. 2. - Z 3. 11. '09: Pgl nr 251, str. 2. - WN nr 2497, str. 6]. - 129*. Głos w dyskusji nad Sprawozdaniem Zarządu Gł. TNSW na XXVI WZgromadzeniu TNSW, 16. 5. '10. - M, XXVI ('10). II. 5. Spr. z 2. Zj. czł. i 26 WZgr. TNSW, str. 545. $-130^{*}$. Głos w ankiecie filologów w sprawie reformy "Ćwiczeń łacińskich dla kl. I.“. - MST, XXVII ('11), I. str. 5. - 131*. Przem. reprezentanta Senatu Akademickiego na Wiecu doktorów Uniwersytetu lwowskiego [w obronie polskości Uniwersytetu] we Lwowie, 21. 12. '12. - Z 23. 12. '12: KLw. nr 591, str. 2. - SłP nr 608, str. 3. - Zob też DzP nr 350, str. 2. - GN nr 297 z 24. 12. '12, str. 2. - GW nr 1056 z 25. 12. '12, str. 7. - 132*. Powitanie Zjazdu członków TNSW w Wiedniu, 6. 6. '15, wygłoszone imieniem Uniwersytetu lwowskiego. - WKP nr 205 z 7. 6. '15, str. 2. - 133*. Przem. na Komisji planów i podręczników szkolnych TNSW we Lwowie, 25. 3. '16. - (z). - GP nr 2809 z 26. 3. str. 2. - Zob. też WN nr 4444 z 28. 3. '16, str. 3. - 134*. Przem. na inauguracji "Odczytów wojennych" we Lwowie, 18. 5. '16. - GW nr 2907 z 19. 5. '16, str. 3. - Zob. też KLw nr 254 z 19. 5. '16, str. 3. WN nr 4490 z 21. 5. '16, str. 6. - 135*. Przem. na otwarciu Kursu dokształcającego dla nauczycieli szkół średnich we Lwowie. - GLw. nr 8. z 11. 1. '22, str. 5.

\section{VARIA}

293. PRZEDMOWA do Przepisów Egzaminacyjnych dla kandydatów na nauczycieli szkół średnich. str. 5-6 Odbitki z Muzeum. [Zob. poniżej nr 350]. - 294. Głos W ankiecie: CZEGO NAJGORĘCEJ NALEŻY NAM ŻYCZYĆ SOBIE W R. 1912? - GN, Dodatek do nru 299 z 31. 12. '11, str. (nl.) 2. - 295. Pismo DO REDAKCJI SŁOWA POLSKIEGO w sprawie artykułu: 136*. „Minister Hussarek i Ukrainofile“, zamieszczonego w Słowie Polskim nr 416 z 6. 9. '12, str. 3. - SłP nr 428 z 13. 9. '12, str. 7. - 296. POLACY NA ZJAZDACH MIĘDZYNARODOWYCH. - GN nr 100 z 2. 5. '14, str. 3. - KLw. nr 171 z 28. 4. '14, str. 2. - KW nr 117 z 29. 4. '14. str. 3. - SłP nr 174 z 29. 4. '14, str. 5. Zob. też GLw. nr 99 z 2. 5. '14, str. 3 (Przedruk, bez podpisu). - 297. DOM AKADEMICKI W WIEDNIU. - WKP nr 48 z 23. 11. '14, str. 2. 298. List z 15. 5. 1915, kartka z 22. 6. 1915 i kartka z 23. 6. 1915 do Prof. 
Dra A. BECKA. W książce: Beck A., Uniwersytet J. K. we Lwowie podczas inwazji rosyjskiej w r. 1914/15. Lw., Senat Akademicki U. J. K. 1935. str. 84, 85-6. - Trzy listy Prof. Becka do K. Twardowskiego. - Tamże, str. 83-4, 85. - 299? [Autentyczność wątpliwa]. Dwa pisma Senatu Akademickiego Uniwersytetu lwowskiego, podpisane przez K. Twardowskiego (jako Rektora): a) do UNIWERSYTETU WARSZAWSKIEGO na uroczystość jego otwarcia. - Z 25. 11. '15: GP nr 2586, str. 2; KLW. nr 443, str. 2. - b) do H. SIENKIEWICZA z powodu ukończenia przezeń 70. roku życia. - KLw. nr 227 z 5. 5. '16, str. 2. - Z 6. 5. '16: DzP nr 220, str. 1; GW nr 2281, str. 2. - Z 9. 5. '16: GLw. nr 106, str. 3-4; WN nr 4479, str. 3-4. - 300. FUNDUSZ ZAPOMOGOWY POLSKIEJ MŁODZIEŻY AKADEMICKIEJ. (Lwów, 1918). Str. 1. - 301. ŻYWY POMNIK. (Fundusz pomocy narodowej im. T. Rutowskiego). - Z. 3. 4. '18: GLw. nr 75, str. 4-5. - GW nr 4084, str. 4-5. - KLw. nr 152, str. 2. - WN nr 5065, str. 4. - GP nr 4085 z 4. 4. '18, str. 2. - 302. PISMO KONDOLENCYJNE z powodu śmierci T. RUTOWSKIEGO wysłane imieniem Uniwersytetu lwowskiego do Komisarza rządowego m. Lwowa, Dra Wł. Stesłowicza. - GLw. nr 77 z 5. 4. '18, str. 3. - WN nr 5066 z 4. 4. '18, str. 4-5.

303.-339. MEMORIAŁY, PETYCJE, PISMA, LISTY, TELEGRAMY ITP. do Rady Szkolnej Krajowej, do Sejmu, do posłów polskich do Rady Państwa itp., wysyłane w różnych sprawach TNSW imieniem jego Wydziału i Zarządu Głównego przez Kazimierza Twardowskiego (jako Przewodniczącego Twa) wspólnie z K. Jareckim, Drem Semkowiczem i K. Zagajewskim (jako kolejnymi Sekretarzami Twa). - M, XXI ('05), str. 1056; XXII ('06). I. 5. Spr. TNSW za czas od 11. 6. '05 do 30. 4. '06, str. 62-5. - MST, XXII ('06). II. str. 89-90. - XXIII ('07). I. str. 10-11; 68-70; II. 28; XXIV ('08), I. str. 105-6; 142-4; 144; 144-5; 146-7; 147-8; II. str. 47; 47-8; 98; 99-100; XXV ('09). I. str. 45; 48-9; 49-50; 90; 91-2; 93; 173-4; II. str. 10; 65-6; 82; 82-4; 116-7. - XXVI ('10). II. str. 10; 56-9; 59-62; 62-9; 87-9. - XXVII ('11). I. str. 53; 83; 84; II. str. 9-10.

\section{SPRAWOZDANIA I PUBLIKACJE O CHARAKTERZE INFORMACYJNYM}

340. POWSZECHNE WYKEADY UNIWERSYTECKIE WE LWOWIE. SPRAWOZDANIE Z CZYNNOŚCI W R. SZK. 1900/01. Lwów, 1901, str. 44. - 341. DTTO ZA ROK AK. 1901/02. - Lwów, 1902, str. 34. 342. DTTO ZA R. AK. 1902/03. Lwów, 1903, str. 32. - Pdr. Zakończenia tegoż Sprawozdania. - SłP nr 181 z 16. 4. '04, str. 4. - 343. Wiadomości bieżące, podane w t. II, r. XXVII ('11). Muzeum. [Podpisane: K. T. - Litery te są skrótem podpisu Kazimierza Twardowskiego. Zob. Sochaniewicz K. W., W "40-lecie Muzeum”, (por. niżej nr 295*) str. 121, poz. 277.]: 1. SEMINARIUM NAUKOWO-PEDA- 
GOGICZNE, str. 351. - 2. W SPRAWIE POBORÓW NADZWYCZAJNYCH PROFESORÓW AUSTRJACKICH UNIWERSYTETÓW I POLITECHNIK. str. 446. - 3. SPRAWA SZKOLNA W PROJEKCIE WYODRĘBNIENIA GUB. CHEŁMSKIEJ. str. 449-50. - 4. WYŻSZE KURSY PRZEMYSŁOWO-ROLNICZE W WIEDNIU. str. 450-1. - 5. PROJEKT UNIWERSYTETU HAMBURSKIEGO. str. 464. - 6. JUBILEUSZ UNIWERSYTETU W JASSACH. str. 464. - 344. Wiadomości bieżące podane w t. I. r. XXVIII ('12). Muzeum. (Podpisane K. T.): 1. 40-LECIE WARSZAWSKIEGO TWA NAUKOWEGO. str. 156-8. - 2. NOWA PRACOWNIA BIOLOGICZNA W WARSZAWIE. str. 158. 3. STYPENDIUM POLSKIE PRZY UNIWERSYTECIE KIJOWSKIM. Tamże. - 4. POLSKA MACIERZ SZKOLNA W PETERSBURGU. Tamże. - 345. Recenzja książki: Nowowiejska J.: Porozbiorowe dzieje Polski. - M, XXXVI ('21), str. 93 (podpis: K. T.). - 346. WSTĘP i WSKAZÓWKI DLA KANDYDATÓW w „Przepisach egzaminacyjnych dla kandydatów na nauczycieli szkół średnich". (Zob. poniżej nr 350). str. 7-10 (217-20) i 64-83 (274-93).

\section{PRZEKŁADY}

347. Kreibig J. KI. Pokusy św. Antoniego. Legenda psychologiczna. - Prz. I. (1895). nr 17 z 14. 9. str. 525-38. [Bez podpisu. Uw. na str. 525 podpisana: K. T. Autentyczność przekładu poświadczona przez nr 206 niniejszej Bibligrafii]. - 348. Tenże. Maria Magdalena i trzy stopnie jej miłości. Tamże, str. 979-89. [Bez podpisu, Autentyczność poświadczona jw.]. - 349. (Lutosławski W.) Naród in-dywidualistyczny. (Un peuple individualiste). Tamże, str. 193-204. [Bez podpisu. Autentyczność poświadczona jw.]. - 350. Przepisy egzaminacyjne dla kandydatów na nauczycieli szkół średnich. - M, XXVII ('11). II. str. 217-293. (Bez podpisu). - Także w odbitce z dodaniem słów: „Wydał Dr Kazimierz Twardowski" oraz Przedmowy. Lwów, 1911, Str. 83.

\section{DZIAŁALNOŚĆ REDAKCYJNA}

Kazimierz Twardowski był od r. 1899 członkiem Redakcji stworzonego przez lwowski Związek Naukowo-Literacki wydawnictwa „Wiedza i Życie". - W latach 1905-1911 stał na czele Komitetu Redakcyjnego miesięcznika "Muzeum”, wydawanego przez TNSW; w skład tegoż Komitetu Redakcyjnego wchodził też w latach 1912-14 i 1915 do maja 1917. 


\section{Literatura o Kazimierzu Twardowskim}

\section{LITERATURA DOTYCZĄCA POGLĄDÓW FILOZOFICZNYCH K. TWARDOWSKIEGO}

Recenzje, analizy i sprawozdania dotyczące poszczególnych prac filozoficznych K. Twardowskiego, podane są powyżej w dziale A niniejszej Bibliografii pod numerami: $1^{*}-98^{*}$.

137*. Kozłowski W. M. Współczesna polska literatura filozoficzna. - A, C (1900). 4. str. 371 i 379. - 138*. Struve H., Wstęp krytyczny do filozofii. 3. wyd. Wwa, '03, str. 590. Zob. też str. 195. - 139*. Tenże, La philosophie en Pologne pendant les dix dernières années (18941904). Extrait des Comptes rendus du II. Congrès International de Philosophie. Genève, '04, p. 347. - To samo rozszerzone pt. „Die polnische Philosophie der letzten 10 Jahre (1894-1904)". - AGPh, XVII '05. p. 559-61; 573-4. (Także w odbitce, Brl., '05). - To samo w przekładzie polskim K. Króla pt. „Filozofia polska w ostatnich 10 latach". Wwa, '07, str. 46-8, 67-8. - 140*. Łukasiewicz J. rec. nr 139*. $\mathrm{PF}, \mathrm{X}$ ('07). str. 338, 342, 343 i 345 [zawiera pewne sprostowania dotyczące poglądów Twardowskiego]. - 141*. Kastil A. Studien zur neuren Erkenntnistheorie. I. Descartes. Halle, Niemeyer '09. Anhang II. I. Abschnitt: Twardowski's Lehre vom Inhalt und Gegenstand der Vorstellungen. str. 180-94. - Zob. też 196, uw. 2; 205; 207-8. - 142*. Stögbauer A., O wyobrażeniach ogólnych. Przyczynek do psychologii wyobrażeń. Lw. '10. (Wydawnictwo PTF. T. IV.) Sgł. Altenberg, str. XII. 134). - 143*. Struve H. Historia logiki jako teorii poznania w Polsce. Wwa, '10. str. 390-395. - Zob. też str. 8. - 144*. Eisler R. Philosophen-Lexikon. Brl., '12, p. 771. - 145*. Tennerówna D. Istnienie jako "treśćc sądzenia i sądu. Uwagi na marginesie teorii sądu Prof. Twardowskiego. - PF, XVII ('14). str. 465-83. - 146*. II. Sprawozdanie Warszawskiego Instytutu Filozoficznego. - PF, XXI ('18). 3. 4. str. 188. [O projekcie słownika terminologicznego podanym przez K. Twardowskiego i realizacji tego projektu w Warszawskim Instytucie Filozoficznym]. Zob. RF, V ('19-20). str. 60-1. - 147* Czeżowski T. Die polnische Philosophie. § 6. Einzeldisziplinen. p. 323. W Ueberwega Grundriss der Geschichte der Philosophie. 12. Aufl. Hg. v. T. K. Oesterreich. Brl. '28. - 148*. Blaustein L. Husserlowska nauka o akcie, treści i przedmiocie przedstawiania. Lw., '28. § 4. Twardowski. str. 11-18. - Zob. też str. 19, 20, 21, 22. - 149*. Linke P. F. Grundfragen der Wahrnehmungslehre. 2. vermehrte Aufl. München, '29. str. 80; 81; 83-84; 97; 96. - 150*. Czeżowski T. Die polnische Philosophie der Gegenwart. - Sl. R. I ('29). str. 439-40. - 151*. Blaustein L. Przedstawienia imaginatywne. Studium z pogranicza psychologii i estetyki. 
Lw., '30, str. 7, 8-13. - 152*. Blausteinowa z Ginsbergów E. W sprawie pojęć samoistności i niesamoistności. - Ks. Pam. PTF, Lw., '31. $\S 3$. Analiza określeń Twardowskiego. str. 149-52. - 153*. Witwicki T. O stosunku treści do przedmiotu przedstawienia. - Tamże. 2. Treść i przedmiot przedstawienia u Twardowskiego i jego następców. - 3 . Stosunek treści do przedmiotu przedstawienia na gruncie teorii pojęć Twardowskiego i Husserla. str. 403-6. Zob. też str. 409, 410. -154*. Tvrdý J. O filosofii polské. Prednásky Slovanského Ustavu w Praze. Svazek III. '32. str. 130, 131. - 155*. The Psychological Register. Ed. by C. Murchison. Worcester, Mass., '32. str. 1126-7. - 156*. Gościcki Th. Les tendances actuelles de la philosophie polonaise. - Recherches Philosophiques, P, II ('32-33). p. 449. - 157*. Ajdukiewicz K. Logistyczny antyirracjonalizm w Polsce. - PF, XXXVII ('34). str. 400-2; zob. też 406; 408. - To samo po niemiecku: Der logistische Antiirrationalismus in Polen. - Erkenntnis, Lg, V ('35). 1. 2. p. 152-4; 160; 161. - 158*. Kotarbiński T. Grundlinien und Tendenzen der Philosophie in Polen. - Sl. R. V ('33). p. 218-220; 220-4. - 159*. Kieszkowski B. Le correnti filosofiche in Polonia. - Estratto dal: Archivio di storia della filosofia. Roma. II ('33). 2. - 160*. Witwicki T. Locke'a teoria idej ogólnych i jej dzieje. - PF, XXXVII ('34). str. 136-8; 147; 149. $161^{*}$. Tenże. O reprezentacji czyli o stosunku obrazu do przedmiotu odtworzonego. Lw., '35. (Archiwum Twa naukowego we Lwowie. Dz. B. Tom XVI. z. 2). Rozdz. IV. § 26. Teoria pojęć Twardowskiego. str. 79-82. - § 27. Porównanie teorii pojęć Twardowskiego z analizą przeżyć reprezentacyjnych. - str. 82-9. § 28. Przedstawienie przedmiotu reprezentowanego jako wytwór przeżycia logiczno-reprezentacyjnego. str. 89-90. - 162*. Zawirski Z. Les tendances actuelles de la philosophie polonaise. - Revue de Synthèse, X ('35). str. 141. - 163*. Ingarden R. Wandlungen der philosophischen Atmosphäre in Polen. - Sl. R. IX ('37). str. 224-8. 164*. Iwanicki J. Ks. Kazimierz Twardowski, filozof. - Ateneum Kapłańskie, Włocławek, kwiecień '38, str. 389-402. - 165*. Blaustein L. Rola Kazimierza Twardowskiego w filozofii niemieckiej na przełomie XIX i XX wieku. Autoreferat odczytu wygłoszonego na 366 pos. naukowym PTF, 5. 3. '38. - Zob. poniżej w dziale Wykłady, Odczyty, Referaty. - 166*. Rundstein H. Sylwetka filozoficzna K. Twardowskiego. - Przemówienie na Akademii ku czci K. Twardowskiego w Łodzi, 7. 4. '38. (Streszczenie H. Kowalskiej). - Zob. poniżej w artykule: Ku uczczeniu pamięci K. Twardowskiego. $-167^{*}$. Łubnicki N. Twardowski jako etyk. Przemówienie jw. (Streszczenie jw.). - Tamże. - 168*. Rajsfeldowa M. Stanowisko Twardowskiego wobec pewnych zagadnień psychologicznych. - Przemówienie jw. (Streszczenie jw.). - Tamże. - 169*. Goldblum N. Rytm dziejów myśli ludzkiej w ujęciu Twardowskiego. - Przemówienie jw. (Streszczenie jw.). - Tamże. - 170*. Ingarden R. Działalność na- 
ukowa K. Twardowskiego. Autoreferat przemówienia na Akademii ku czci K. Twardowskiego we Lwowie, 30. 4. '38. - Tamże. - Zob. też m. in.: Winter E., Religion und Offenbarung in der Religionsphilosophie Bernard Bolzanos. Breslau, '32. [O „odkryciu” Bolzany przez Twardowskiego (1894) i Husserla (1900/01)]. - Por. rec. tej książki w Theologische Revue, XXXV. 5. szpalta 193. Munster i. W., '36. Baumgarten J. Co Polska wniosła do nauki światowej. - Na Szerokim Świecie, Kr., nr 52 z 27. 12. '36, str. 10.

\section{LITERATURA DOTYCZĄCA BĄDŹ CAŁOKSZTAŁTU DZIAŁALNOŚCI NA POLU FILOZOFII (LUB POSZCZEGÓLNYCH JEJ PRAKTYCZNYCH DZIEDZIN), BĄDŹ CAŁOKSZTAŁTU DZIAŁALNOŚCI K. TWARDOWSKIEGO W OGÓLE}

171*. Sprawozdania Kółka Filozoficznego Czytelni Akademickiej. - Spr. Czytelni Akademickiej we Lwowie za r. 1895/6 (Lw. '96), str. 28; za r. 1896/7 (Lw. '97), str. 34; za r. 1897/8 (Lw. '98), str. 34; za r. 1898/9 (Lw. '99), str. 22; za r. 1899/1900 Lw. (1900), str. 30. - Za r. 1900/01 (Lw. '01), str. 40; za r. 1901/02 (Lw. '02), str. 51; za r. 1902/03 (Lw. '03), str. 62; za r. 1903/04 (Lw. '04), str. 76; za r. 1904/05 (Lw. '05), str. 6267; za r 1905/06 (Lw. '06), str. 81; za r. 1906/07 (Lw. '07), str. 87; za r. 1907/08 (Lw. '08), str. 73; za r. 1908/09 (Lw. '09), str. 72; za r. 1910 (Lw. 1911), str. 32; za r. 1911 (Lw. 1912), str. 32. - 172*. Sprawozdania Kółka filozoficznego we Lwowie. - PF, VI ('03), str. 114; VII ('04), str. 105; VIII ('05), str. 105-6; IX ('06), str. 320-2; XI ('08), str. 253. - 173*. Flach J. Dr w recenzji Vaihingera, Filozofia Nietzschego w przekładzie K. Twardowskiego. - PP, CLIV ('04), str. 144. - 174*. Wołowicz L. Uczczenie Prof. Twardowskiego. - SłP. nr 456 z 23. 11. '05, str. 6. 175*. Weryho Wł. na str. IV i V publikacji: Dziesięciolecie Przeglądu Filozoficznego. Wwa, 1907. - 176*. [O grożącym strajku słuchaczy filozofii z powodu zbyt szczupłej sali nie mogącej pomieścić 900 zapisanych na wykłady Twardowskiego słuchaczy i o załatwieniu tej sprawy przez przeniesienie wykładów do sali koncertowej Galicyjskiego Twa Muzycznego:] GLw. nr 250 z 31. 10. '08, str. 4; nr 252 z 3. 11. '08, str. 3-4. - GN nr 250 z 30. 10. '08, str. 2; nr 254 z 4. 11. '08, str. 2. - KLw. nr 508 z 30. 10. '08, str. 4; nr 513 z 3. 11. '08, str. 2. - Pgl. nr 251 z 30. 10. '08, str. 3; nr 253 z 3. 11. '08, str. 3. - SłP nr 506 z 29. 10. '08, str. 6; nr 512 z 2. 11. '08, str. 7. - (85*). Borowski M. na str. 51-2 w recenzji książki „O filozofii średniowiecznej”. - 177*. Prof. K. Twardowski. - SłP nr 510 z 3. 11. '10, str. 4-5. - 178*. Dr K. Twardowski. KLw. nr 512 z 4. 11. '10, str. 3. - 179*. Uczczenie zasług Prof. Dra K. Twardowskiego przy sposobności setnego posiedzenia Polskiego Twa Filozoficznego. - M, XXVI ('10). II. str. 437-43. (Także w odbitce. Str. 7). - To samo. - PF, XIV ('11). str. 131-7. Zawiera m. in. przemó- 
wienia B. Mańkowskiego i Wł. Witwickiego.-180* Inne artykuły z powodu tejże uroczystości: 100. posiedzenie Polskiego Twa Filozoficznego. - Wkr. I ('10), II. nr 17. str. 158-9. - Polskie Two Filozoficzne. - DzP nr 302 z 5. 11. '10, str. 2. - WN nr 2798 z 5. 11. '10, str. 13. - Zob. też z 6. 11. '10: GLw. nr 252, str. 3. - GN nr 253, str. 3. SłP nr 515, str. 1-2. - 181*. Profesor Twardowski. - Nasz Kraj, Lwów, 12. 11. 1910. str. 10. - 182*. Nowy Rektor magnificus. - GW nr 1942 z 26. 6. '14, str. 2. - 183*. Rektor Kazimierz Twardowski. - KLw. nr 266, z 26. 6. '14, str. 3. - 184*. Z 26. 6. '14; SłP nr 269, str. 3 i WN nr 3885, str. $10 \mathrm{w}$ artykułach: „Nowy Senat Uniwersytetu”. - 185*. Z Uniwersytetu lwowskiego. - KW nr 178 z 30. 4. '14, str. 5-6. - 186*. Von der Lemberger Universität. - Neue Illustrierte Zeitung, Wien Czernowitz, XX ('15). 2 (na str. 5). - 187*. Z powodu 50. rocznicy urodzin Prof. Dra K. Twardowskiego. - KLw. nr 525 z 20. 10. '16, str. 2. 188*. Zł. [Zygmunt Łempicki] Kazimierz Twardowski. - WN nr 620 z 21. 10. '16, str. 5. Zob. też GLw. nr 240 z 22. 10. '16, str. 3. - GP nr 3188 z 21. 10. '16, str. 3. - 189*. 50-lecie polskiego uczonego. Dziennik Cieszyński nr 247 z 27. 10. '16. - 190*. Pożegnanie ustępującego Rektora Uniwersytetu. - KLw. nr 448 z 24. 9. '17, str. 3. - Zmiana Rektora. - GW nr 3767 z 24. 9. '17, str. 3. Zob. też nr 3766 z 23. 9. '17, str. 3. - 191*. Spr. z XIV WZgr. PTF, 24. 5. '19. - RF, V ('19-20). str. $39 \mathrm{~b}$ [O podziękowaniu wyrażonym K. Twardowskiemu z okazji upływu piętnastolecia PTF]. - 192*. Prof. Dr K. Twardowski. - Tamże (Wiadomości osobiste). - 193*. Witwicki Wł. Kazimierz Twardowski. - Ks. Pam. ku uczczeniu 25-letniej działalności nauczycielskiej na katedrze filozofii w Uniwersytecie lwowskim K. Twardowskiego. PF, XXIII ('20). Lw., '21, str. IX-XIX. - 194*. Jubileusz Prof. Dra K. Twardowskiego. - M, XXXVII ('22). str. 460. - Zob. też Prof. Dr. K. Twardowski. - WN nr 4612 z 1. 11. '22, str. 7. - 195*. Zł[empicki]. Lwów a filozofia ( $Z$ okazji I Zjazdu filozofów polskich we Lwowie). - WN nr 6566 z 12. 5. '23, str. 2-3. - 196*. Ingarden R. na str. 3702 recenzji Księgi pamiątkowej jw. pod nr 193*. - Przegląd Warszawski, IV ('24). nr 30. - 197*. Dvornikovič V. Pogledi u noviju polsku filozofiju. - Jugoslavenska Njiva, X ('26). z. 2-6. - 198*. Vorovka K. Wrażenia z Warszawy. Przekład z czeskiego. - RF, X ('26-27). str. 84 b. $-199^{*}$. w. r. Na marginesie II Polskiego Zjazdu Filozoficznego. - PPed. XLVI ('27). str. 689. - Zob. też GP nr 8272 z 25. 9. '27, str. 1. - GLw. nr 220 z 25. 9. '27, str. 1. [Dotyczy m. in. Zagajenia tegoż Zjazdu przez K. Twardowskiego. Zagajenie to jest zachowane w spuściźnie rękopiśmiennej]. - 200*. Jubileusz Polskiego Towarzystwa Filozoficznego. - WN nr 8289 z 8. 2. '29, str. 3. - 201*. Słoniewska H. Polskie Towarzystwo Filozoficzne. - SłP nr 41 z 11. 2. '29, str. 7. 202*. Święto ćwierćwiecza PTF. - SłP nr 44 z 14. 2. '29. - Z 15. 2. '29: (A. W.) Dwudziestopięciolecie PTF we Lwowie. - WN nr 8295, str. 4; 
Dtto - DzP nr 46, str. 9. Zob. też RF, XI ('28-29). str. 199-200 i 216 b. 203*. Wysokie odznaczenie Prof. Twardowskiego. - DzP nr 50 z 19. 2. '29, str. 2. - Prof. Twardowski doktorem honorowym Uniwersytetu warszawskiego. - GLw. nr 40 z 17. 2. '29, str. 4. - GP nr 8775 z 17. 2. '29, str. 14. - Uczczenie Prof. Twardowskiego. - SłP nr 46 z 16. 2. '29, str. 4. - Zaszczytne odznaczenie Prof. Twardowskiego. - WN nr 8298 z 19. 2. '29, str. 8. - 204*. Łukasiewicz J. w „O znaczeniu i potrzebach logiki matematycznej". - NP, X ('29), str. 607. - 205*. Blaustein L. Das 25-jahrige Jubiläum der Polnischen Philosophischen Gesellschaft. - S1. R. II ('30). p. 229-30. - 206*. Kleiner J. Kazimierz Twardowski. - PH, V ('30). 3. str. 360-5. - Pdr.: DzLw. nr 154 z 7. 6. '30, str. 6; nr 155 z 8. 6. '30, str. 6; nr 156 z 9. 6. '30, str. 6-7. - 207*. Łempicki St. Prof. Twardowski żegna się z Uniwersytetem. - GLw. nr 105 z 8. 5. '30, str. 3-4. - Zob. DzLw. nr 125 z 9. 5. '30, str. 6. - 208*. Blaustein L. Kazimierz Twardowski. - Chw. nr 4037 z 22. 6. '30, str. 9-10. - 209*. m. n. Kazimierz Twardowski profesorem honorowym Uniwersytetu J. K. - SłP nr 175 z 30. 6. '30, str. 5. - 210*. Straszewski M. Historia filozofii w Polsce. Przerobił i uzupełnił Ks. Fr. Kwiatkowski. Nadbitka z 3. wyd. „Historii filozofii w zarysie” Dra A. Stoeckla i Dra J. Weingartnera w opr. Ks. Fr. Kwiatkowskiego. str. 63-4. - 211*. Kazimierz Twardowski profesorem honorowym Uniwersytetu J. K. - GP nr 9457 z 13. 1. '31, str. 4. - Wręczenie medalu pamiątkowego Prof. Twardowskiemu. - Z 13. 1. '31: GLw. nr 9, str. 5; SłP nr 12, str. 2; WN nr 8870, str. 8. - Zob. też RF XII ('30-31). str. 271-2. $-212^{*}$ Tatarkiewicz Wł. na str. 288 (i 285) t. II. wyd. 1 Historii Filozofii. Lw., 31. Dtto w wyd. II. Lw., '33. - 213*. Prof. Dr Porębowicz i Prof. Dr Twardowski doktorami honoris causa Uniwersytetu Poznańskiego. - Z 23. 11. '32: GLw. nr 273, str. 4; GP nr 10127, str. 5; SłP nr 322, str. 4. - 214*. Komitet Redakcyjny Biblioteczki Filozoficznej. Przedmowa do wydania "O tak zwanych prawdach względnych" (Bibl. Filoz. t. 3. Zob. powyżej nr 9, Pdr. 2). - 215*. Mańkowski T. Życie naukowe Lwowa. - NP, XIX ('34). str. 154, 155. 216*. Sobociński B. Polskie wydawnictwa filozoficzne w latach 19181936. - Nowa Książka, ('36). str. 113-4; 115. - 217*. D. G[romska]. Profesor K. Twardowski laureatem naukowym m. Łodzi. - WN nr 10471 z 29. 4. '36, str. 2-3. - 218*. S. M[ękarski]. K. Twardowski. Laureat naukowy m. Łodzi. - Gazeta Polska, Wwa, nr 130 z 10. 5. '36, str. 5. - 219*. Ingarden R. Kazimierz Twardowski. - Nowe Czasy, Lwów, nr 9 (42) z 15. 5. '36, str. 4. - 220*. Ostrowski J. Laureat nagrody naukowej $\mathrm{m}$. Łodzi, Prof. K. Twardowski, pionier filozofii naukowej. - Kurier Poranny, Wwa, nr 114 z 16. 5. '36, str. 6. - 221*. Kotarbiński T. Kazimierz Twardowski. - Pion, Wwa, IV ('36). nr 21 z 23. 5. str. 3. - 222*. Dr E. G(insberg) - B(lausteinowa). K. Twardowski jako nauczyciel. - Chw. nr 6175 z 30. 5. '36, str. 10. - 223*. Prof. K. Twar- 
dowski laureatem nagrody m. Łodzi. - Z 26. 4. '36: Kurier Łódzki; Echo; Łódź. - Prof. K. T. laureatem m. Łodzi. - Z 26. 4. '36: Republika, Łódź, nr 114, str. 5; Głos Poranny, Łódź, nr 114, str. 6; KW nr 114, str. 28; - Prof. K. T. laureatem nagrody naukowej m. Łodzi. - IKC nr 116 z 26. 4. '36, str. 14. - 224*. Maśliński J. Twórca filozofii polskiej. (Z powodu 70. rocznicy urodzin prof. K. Twardowskiego). - Kurier Wileński, 20. 10. '36. - 225*. Kotarbiński T. Kazimierz Twardowski. PF, XL ('37). str. 1-7. - Przemówienie nadane dn. 20. 10. 1936 przez wszystkie rozgłośnie Radia Polskiego. - [Zob. Oesterreichisch-Slavischer Pressedienst, W, '36. nr 6. p. 1]. - 226*. Baley S. Prof. Kazimierzowi Twardowskiemu w 70. rocznicę urodzin. - Polskie Archiwum Psychologii, IX ('36/37). str. 65-7. - 227*. Blausteinowa E. Dr. Ruch Filozoficzny Lwowa. - Nasza Opinia, Wwa, IV ('36). nr 61. str. 7. 228*. Nagroda m. Łodzi dla Polskiej Nauki. - RF, XIII. 5-10 ('37). str. 181 b -182 b. - 229*. 70. rocznica urodzin Prof. Twardowskiego. Tamże, str. 183 b -184 b. - Zob. też m. in.: Straszewski M. w t. IV Ueberwega, Grundriss der Geschichte der Philosophie, wyd. 11. Opracował K. T. Oesterreich, Brl., '16. § 100. Die Philosophie in Polen, str. 744 i 746. - Blaustein L. Edmund Husserl i jego fenomenologia. - PH, V ('30). str. 240. - „Czy wiesz, kto to jest?". Wwa, wyd. Gł. Księgarni Wojskowej, '38, str. 761-2. Krótka ta notatka zawiera trzy błędy: Twardowski nazwany tam jest współzałożycielem TNSW i Przewodniczącym Polskiej Akademii Umiejętności w r. 1911, a "Wyobrażenia i Pojęcia“ figurują - w kontekście polskim - jako „Images and corroptions" (sic!). 230*. jot. ha. Zgon Nestora filozofii polskiej. - Kurier Polski, Wwa, 14. 2. '38. (Także: Gazeta Kaliska, 14. 2. '38). - 231*. Łempicki Z. Śp. Kazimierz Twardowski. - KW nr 45 z 15. 2. '38, str. 4. - 232*. Kazimierz Twardowski gestorben. - Prager Presse, nr 45 z 15. 2. '38, str. 8. - 233*. Gromska D. Kazimierz Twardowski. -WN, nr 11.027 z 16. 2. '38, str. 4. -234*. ł. Pan Profesor z rudą brodą. - Dziennik Ludowy, Wwa, 16. 2. '38. - 235*. Mikołajewski Z. Nad grobem znakomitego uczonego. - Kurier Poznański nr 73, wyd. wieczorne z 16. 2. '38, str. 10.- 236*. M(ękarski) S. Kazimierz Twardowski. - Gazeta Polska, Wwa, nr 47 z 17. 2. '38. str. 3-4. - 237*. Kazimierz Twardowski. - Zaczyn, Wwa, nr 2 z 17. 2. '38, str. 3. - 238*. Śniegocki Wł. Kazimierz Twardowski. - Polska Zbrojna, nr 45 z 19. 2. '38, str. 4. - 239*. B(laustein) L. Kazimierz Twardowski. - Chw. nr 6796 z 20. 2. '38, str. 9. - 240*. Gr. J. Śp. Kazimierz Twardowski. Myśl Narodowa, Wwa, nr 8 z 20. 2. '38, str. 125-6. - 241*. Grzelecki St. „Najmędrszy z Polaków“. O Kazimierzu Twardowskim. - ABC, Nowiny Codzienne, Wwa, nr 54 z 20. 2. '38, str. 6. - 242*. Koller J. Wielki wychowawca, śp. prof. Kazimierz Twardowski. - Dziennik Poznański, nr 41 z 20. 2. '38, str. 13. - 243*. Uczony na miarę europejską. Zgon Nestora filozofii polskiej. - Kurier Łódzki, 20. 2. '38. - To 
samo. - Dziennik Kresowy, Grodno, 27. 2. '38. - 244*. Finkielsztein L. Zgon filozofa polskiego, Prof. Dra K. Twardowskiego. - Nasz Przegląd, Wwa, nr 55 z 23. 2. '38, str. 6. - 245*. Milbrandt M. Kazimierz Twardowski. - Naród i Państwo, Wwa, III ('38). nr 78 z 27. 2. '38, str. 5. - 246*. Pannenkowa I. Śp. Kazimierz Twardowski. Filozof i „człowiek szczęśliwy”. - Polonia, Katowice, nr 4801 z 27. 2. '38, str. 8-9. - 247* Łempicki St. Columna Universitatis. - DzP nr 58 z 28. 2. '38, str. 10. - 248*. Czesi o zmarłym prof. Twardowskim. - Krakowski Kurier Wieczorny, 1. 3. '38. - 249*. Kahane J. Ks. Śp. profesor dr. K. Twardowski. - Przegląd Ewangelicki, Wwa - Bydgoszcz Łódź, V ('38). nr 10 z 6. 3. '38, str. 116. - 250*. Zawirski Z. Kazimierz Twardowski (1866-1938). - Czas, Wwa, 6. 3. '38. (Także w odbitce [rozszerzonej]. Kr., '38, Str. 4. Zł 0.50. Biblioteczka Czasu, Nr 6). $251^{*}$. Ostrowski-Naumoff J. Po zgonie śp. Prof. K. Twardowskiego. Szlachetnej pamięci prawdziwego mędrca. - Kurier Poranny, Wwa, nr 67 z 8. 3. '38, str. 3. - 252*. S z(arlitt) B. Gedenkworte für Prof. Dr K. v. Twardowski. - Neue Freie Presse, W, nr 26398 z 8. 3. '38, str. 8. 253*. Kleiner J. Kazimierz Twardowski. - Pion, Wwa, VI ('38). nr 10 (23) z 13. 3. '38, str. 2-3. - 254*. Witwicki Wł. Kazimierz Twardowski. Epitafium. - Polskie Archiwum Psychologii, Wwa, X ('37/38). str. 3132. - 255*. Błachowski S. Kazimierz Twardowski. - Kwartalnik Psychologiczny, Poznań, X ('38), 1. 2. str. 1-8. - 256. Kazimierz Twardowski. - Sl. R. X ('38). 2. str. 152. - 257*. Hirschberg A. Dr. Z moich wspomnień: Kazimierz Twardowski. - Kurier Powszechny, Wilno, nr 91 (500) z 3. 4. '38, str. 4. - 258*. I(lja). E[psztejn]. Prof. Dr K. Twardowski. - Akademia ku czci Wielkiego Uczonego i Pięknego Człowieka. - Głos Poranny, Łódź, 15. 4. '38. - 259*. Witwicki Wł. Kazimierz Twardowski. - Wiadomości Literackie, Wwa, XV ('38). nr 18 z 24. 4. str. 1. - 260*. Ten, co rozbudził w Polsce zainteresowanie dla filozofii. - Kurier Literacko - Naukowy, nr 18, str. XII; dodatek IKC, nr 120 z 2. 5. '38. - 261. Hirschler J. Przemówienie na Dorocznym posiedzeniu publicznym Twa Naukowego we Lwowie, 14. 5. '38. (M. in. o K. Twardowskim). - DzP nr 137 z 20. 5. '38, str. 3. - 262*. Kazimierz Twardowski. - Szkoły Wyższe, Organ Sekcji Szkół Wyższych Z. N. P. Wwa, I. 1. czerwiec '38, str. 22-23. - 263*. Czeżowski T. Kazimierz Twardowski. - RF, XIV ('38). str. 2-9. - 264*. Czerny Z. Przemówienie u trumny Kazimierza Twardowskiego. - Tamże, str. 9-11. 265*. Ingarden R. - Dtto - Tamże, str. 11-12. - 266*. Kotarbiński T. Dtto. - Tamże, str. 12-13. - 267*. Czeżowski T. Przemówienie na Akademii żałobnej ku czci K. Twardowskiego we Lwowie 30. 4. '38. (Streszczenie na podstawie rękopisu). - Tamże w artykule: Ku uczczeniu pamięci K. Twardowskiego. - 268*. Brodzka R. Twardowski jako pedagog i organizator. (Streszczenie H. Kowalskiej). - Tamże. 


\section{LITERATURA DOTYCZĄCA DZIAŁALNOŚCI POZAFILOZOFICZNEJ K. TWARDOWSKIEGO}

Recenzje i sprawozdania dotyczące poszczególnych publikacji i poczynań niefilozoficznych $\mathrm{K}$. Twardowskiego podane są w dziale B niniejszej Bibliografii pod numerami: $99^{*}-136^{*}$.

269*. [O roli Twardowskiego w czasie zajść uniwersyteckich w r. 1901]: 1. Skandaliczny wiec. - SłP nr 543 z 10. 11. '01, str. 3. - 2. Ingoizm ruski. - GN nr 322 z 20. 11. '01, str. 2. - WN nr 102 z 20. 11. '01, str. 5. - Demonstracje ruskiej młodzieży. - KLw. nr 322 z 20. 11. '01, str. 4 i nr 324 z 22. 11. '01, str. 6. - Zajścia na Uniwersytecie. - SłP nr 544 z 21. 11. '01, str. 5. - Po ruskiej „borbie“ na Uniwersytecie. Przedświt, Lw., 23. 11. '01, str. 5. - 3. Po zamknięciu Uniwersytetu. - SłP nr 546 z 22. 11. '01, str. 5. - 4. Owacja dla Prof. Twardowskiego. - Tamże, nr 551 z 25. 11. '01, str. 2. - GN nr 326 z 24. 11. '01, str. 2. - zob. nr 328 z 26. 11. str. 2 i 330 z 28. 11. '01, str. 2. - Echa demonstracyj ruskich. - Przedświt, Lw., 26. 11. '01, str. 5. - 5. Echa Uniwersyteckie. - SłP nr 564 z 3. 12. '01, str. 5. 270*. Franko I. Das Polentum nach zwei Fronten. - Die Zeit, W, XXIX ('01). nr 376 z 14. 12. str. 164. - Sprostowanie pod tym samym tytułem. - Tamże, nr 378 z 28. 12. str. 194. - Amicus mihi Dr Franko, sed magis amica veritas. - NR, nr 291 z 18. 12. '01, str. 1. - 271*. Podziękowanie Wiecu słuchaczów filozofii. - SłP nr 510 z 22. 10. '02, str. 5. - 272*. Uchwała XXII. WZgromadzenia TNSW, 5. 6. '06 (Podziękowanie i uznanie dla Prof. Twardowskiego). - M, XXII ('06). Spr. z tegoż WZgr. str. 18-9. [Zob. Cz. nr 127 z 5. 6. '06, str. 2 i z 6. 6. '06: DzP nr 249, str. 1. - GLw. nr 129 z 7. 6. '06, str. 4. - GN nr 123, str. 2]. - 273*. Podziękowanie Wydziału TNSW za wystąpienie w obronie nauczycielstwa. - MST, XXIV ('08). I. str. 79. - 274*. Podziękowanie wyrażone Prezesowi na XXIV WZgr. TNSW dn. 7. 6. '08. - M, XXIV ('08), II. z. 2. Spr. z tegoż WZgr. str. 44. - 275*. Karbowiak A. TNSW 1884-1908. Dodatek I do r. XXV ('09). Muzeum. Passim, zwł. str. 8; 179; 180. (Cf. Spis osób s. v. Twardowski, str. 183). - 276*. Podziękowanie Koła krakowskiego TNSW za obronę nauczycielstwa, tudzież za usilne starania o rozwój Twa. - MST, XXV ('09). I. str. 106. - 277*. Podziękowanie wyrażone Prof. Twardowskiemu na XXVI WZgr. TNSW dn. 16. 5. '10. - M, XXVI ('10). II. 5. Spr. z tegoż WZgr. str. 55. - [Zob. Cz. nr 219 z 17. 5. '10, str. 1. - SłP nr 225 z 18. 5. '10, str. 1]. - 278*. Prywatne Gimnazjum żeńskie im. Słowackiego. (O adresie dla ustępującego ze stanowiska swego Prezesa Twa i utworzeniu w zakładzie 2 miejsc stypendyjnych im. K. Twardowskiego). - GLw. nr 272 z 30. 11. '10, str. 3. - SłP nr 522 z 28. 11. '10. str. 6. - Zob. też z 29. 11. '10: DzP nr 326, str. 2; KLw. nr 553, str. 3. - GN nr 273 z 30. 11. '10, str. 2. - 279*. Owacja dla Prof. Twardowskiego. - DzP nr 152 z 6. 6. '11, str. 2. Por. 
M, XXVII ('11), II. 5. str. 45. - 280*. Kallenbach J. Przem. na XXVII WZgr. TNSW, 5. 6. '11, [przy objęciu złożonej przez K. Twardowskiego prezesury TNSW]. - Tamże, str. 51-2. - 281*. [Zagajewski K.] Wstęp do Księgi Pamiątkowej: K. Twardowski, Mowy i Rozprawy (zob. wyżej nr 283). str. VII, VIII. - Rozwój TNSW w latach prezesury Prof. Twardowskiego (1905-1911) przedstawiony cyframi. - Tamże, str. 259-67. (Wyczerpujący pogląd na działalność i rolę Kazimierza Twardowskiego w TNSW daje jedynie lektura "Spraw Towarzystwa”, dodatków do „Muzeum” z lat 1905-1911.) - 282*. Biuro porady dla akademików lwowskich. - WKP nr 2 z 29. 9. '14, str. 2. - 283*. Zgromadzenie młodzieży Wszechnicy Jagiellońskiej. - WKP nr 54 z 30. 11. '14, str. 5. - 284*. W sprawie zasiłków dla młodzieży akademickiej. - WKP nr 67 z 16. 12. '14, str. 2. - 285*. Z życia młodzieży akademickiej. - WKP nr 89 z 15. 1. '15, str. 3. - 286*. Dom Akademicki. - WKP nr 143 z 20. 3. '15, str. 5. - 287*. Rektor Dr Twardowski o młodzieży. - WKP nr 154 z 3. 4. '15, str. 3. - 288*. Podziękowanie [młodzieży "Domu Akademickiego"] Rektorowi Drowi Twardowskiemu. - WKP nr 157 z 8. 4. '15, str. 6. - Zob. też „Ważne dla lwowskiej młodzieży prawniczej”. - WKP nr 168 z 21. 4. '15, str. 6. - 289*. Die Universität Lemberg. - Ukrainisches Korrespondenzblatt, Wien, nr 32/33 z 19. 8. '15, str. 4. - 290*. 1) Bandrowski J. O germanizacji. Gazeta Polska, Moskwa, nr 67 (134) z 8 (21). 3. '16. - 2) Tamże, nr z 31. 3. (13. 4.) '16. - Odpowiedzi na te artykuły: 1) Sierpiński W. - Echo Polskie z 9. 4. '16. - 2) Mianowski T., Staff L., Treter M.: List do Redakcji. - Dziennik Piotrogradzki z 7 (20). 4. '16. - Dtto (w skróceniu): Dziennik Kijowski z 5. (18). 4. '16. - Zob. też Wasilewski Z. Nieporozumienie. - Gazeta Polska, Moskwa, 8. (21). 4. '16. - Informacje o tej polemice: 1) W obronie Prof. Twardowskiego. - GW nr 2890 z 10. 5. '16, str. 2. - 2) O polskość Uniwersytetu. - GW nr 2892 z 11. 5. '16, str. 2-3. - 291*. Fundusz pomocy narodowej im. Rutowskiego. - WN nr 4710 z 4. 2. ' 17 , str. 2. - 292*. Pożegnanie ustępującego Rektora Uniwersytetu. - KLw. nr 448 z 24. 9. '17, str. 3. - (d). Zmiana Rektora. - GW nr 3767 z 24. 9. '17, str. 3. - 293*. Numerus clausus. Zjednoczenie, Lwów, listopad 1923, str. 6. - 294*. Majchrowicz Fr. 40-letni jubileusz czasopisma „Muzeum”. W dziele: Muzeum, 18851925. Dodatek 15 do Muzeum, Lw., '25. R. III. Odrodzenie Twa. Najświetniejszy jego okres. Reorganizacja Muzeum. str. 14 i 15. - 295*. Sochaniewicz K. W 40-lecie Muzeum. - Tamże, str. 76-7; 80; 82-4; 85, 86, 87. - 296*. Zagajewski K. Dr, Prof. Dr K. Twardowski jako prezes TNSW. - M, LI ('37). 2. str. 59-66. 297*. Chomsowa L. Ku pamięci Prof. Kazimierza Twardowskiego. - WN, nr 11045 z 9. 3. '38, str. 3. - 298*. [Tatarkiewicz Wł.] Kazimierz Twardowski. (Z przemówienia Prezesa Twa [N. S. W.], wygłoszonego w Warszawie, 9. 5. '38). - PPed. LVII ('38). 14. str. 193-4. 
Do biografii:

Śp. Pius Twardowski. - SłP nr 354 z 8. 8. '06, str. 4-5.

Szpot W. J. A. na str. 2 artykułu: Na bruku wiedeńskim. (M. in. Theresianum. Szczęśliwy Kazio). - Echo, Wwa, nr 189 z 13. (25). 8. 1879, str. 1-2.

Nachtgebet. Wiersz K, Twardowskiego, drukowany jako manuskrypt. Do słów tych skomponował Dr C. Navratil pieśń, która została wykonana w Wiedniu na popisie „Musikalisch-deklamatorische Produktion der Zöglinge der k. k. Theresianischen Akademie", dn. 12. 5. 1880. [Tekst i muzyka zachowane w spuściźnie rękopiśmiennej].

Gra Jankiela. Utwór symfoniczny K. Twardowskiego. Wykonała kompletna orkiestra teatru hr. Skarbka na uroczystym przedstawieniu ku uczczeniu 100 rocznicy Konstytucji 3 Maja, dn. 3. 5. 1891 we Lwowie. [Zachowane w spuściźnie rękopiśmiennej].

Dwie pieśni K. Twardowskiego: 1) do słów Nietzschego i 2) do słów St. Brzozowskiego. Zostały wykonane na Akademii Żałobnej ku czci K. Twardowskiego we Lwowie, dn. 30. kwietnia 1938. (Zob. powyżej w artykule Ku uczczeniu pamięci Kazimierza Twardowskiego).

(Redakcja Ruchu Filozoficznego, pragnąc kontynuować rubrykę bibliografii prac Kazimierza Twardowskiego i literatury o Kazimierzu Twardowskim, prosi czytelników o nadsyłanie sprostowań i uzupełnień ogłoszonej powyżej Bibliografii.) 